OPEN ACCESS

Edited by: Ipek Suntar,

Gazi University, Turkey

Reviewed by:

Md. Areeful Haque, International Islamic University

Chittagong, Bangladesh

Hari Prasad Devkota,

Kumamoto University, Japan

*Correspondence:

Yuandani

yuandani@usu.ac.id

yuan_dani@yahoo.com

Specialty section:

This article was submitted to

Ethnopharmacology,

a section of the journal

Frontiers in Pharmacology

Received: 17 December 2020

Accepted: 18 February 2021

Published: 30 April 2021

Citation:

Yuandani, Jantan I, Rohani AS and Sumantri IB (2021) Immunomodulatory Effects and Mechanisms of Curcuma

Species and Their Bioactive

Compounds: A Review.

Front. Pharmacol. 12:643119.

doi: 10.3389/fphar.2021.643119

\section{Immunomodulatory Effects and} Mechanisms of Curcuma Species and Their Bioactive Compounds: A Review

\author{
Yuandani $^{1 *}$, Ibrahim Jantan ${ }^{2}$, Ade Sri Rohani ${ }^{1}$ and Imam Bagus Sumantri ${ }^{3}$ \\ ${ }^{1}$ Department of Pharmacology, Faculty of Pharmacy, Universitas Sumatera Utara, Medan, Indonesia, ${ }^{2}$ Institute of Systems \\ Biology, Universiti Kebangsaan Malaysia, Selangor, Malaysia, ${ }^{3}$ Department of Pharmaceutical Biology, Faculty of Pharmacy, \\ Universitas Sumatera Utara, Medan, Indonesia
}

Curcuma species (family: Zingiberaceae) are widely utilized in traditional medicine to treat diverse immune-related disorders. There have been many scientific studies on their immunomodulating effects to support their ethnopharmacological uses. In this review, the efficacy of six Curcuma species, namely, C. longa L., C. zanthorrhiza Roxb., C. mangga Valeton \& Zijp, C. aeruginosa Roxb. C. zedoaria (Christm.) Roscoe, and C. amada Roxb., and their bioactive metabolites to modulate the immune system, their mechanistic effects, and their potential to be developed into effective and safe immunomodulatory agents are highlighted. Literature search has been carried out extensively to gather significant findings on immunomodulating activities of these plants. The immunomodulatory effects of Curcuma species were critically analyzed, and future research strategies and appropriate perspectives on the plants as source of new immunomodulators were discussed. Most of the pharmacological investigations to evaluate their immunomodulatory effects were in vivo and in vitro experiments on the crude extracts of the plants. The extracts were not chemically characterized or standardized. Of all the Curcuma species investigated, the immunomodulatory effects of $C$. longa were the most studied. Most of the bioactive metabolites responsible for the immunomodulating activities were not determined, and mechanistic studies to understand the underlying mechanisms were scanty. There are limited clinical studies to confirm their efficacy in human. Of all the bioactive metabolites, only curcumin is undergoing extensive clinical trials based on its antiinflammatory properties and main use as an adjuvant for the treatment of cancer. More indepth studies to understand the underlying mechanisms using experimental in vivo animal models of immune-related disorders and elaborate bioavailability, preclinical pharmacokinetics, and toxicity studies are required before clinical trials can be pursued for development into immunomodulatory agents.

Keywords: curcuma species, ethnopharmacology, phytochemicals, immunomodulation, immune system

\section{INTRODUCTION}

The human body has a remarkably sophisticated immune system consisting of white blood cells and specialized immune molecules that protect the body against invading pathogens (Tan and Vanitha, 2004). The immune system is made up of innate and adaptive immune immunity. Innate immunity provides first protection against pathogens, and then it will stimulate adaptive immunity to enhance 
the protection. Innate immunity is the most rapidly acting immunity. It mostly depends on neutrophils, macrophages, dendritic cells, and monocytes, while $\mathrm{T}$ and $\mathrm{B}$ cells are involved in adaptive immunity (Beutler, 2004; Saroj et al., 2012). In response to pathogens, leukocytes perform a number of phagocytic activities, including chemotaxis, leukocytes adhesion to vascular endothelial cells, and pathogen engulfment, followed by intracellular killing to eliminate the pathogens (Beutler, 2004; Kobayashi et al., 2005). Phagocytes migrate toward the chemoattractants such as complement $(\mathrm{C} 3 \mathrm{a}$ and C3b) and formyl methionyl-leucyl-phenylalanine (fMLP) (a bacterial product) (Luster, 2001). Chemoattractants utilize a similar signal transduction system, namely, G protein-coupled receptor, that is, platelet-activating factor receptor (PAFR), formyl-methionyl-leucyl-phenylalanine receptor (fMLPR), and complement $\mathrm{C} 5 \mathrm{a}$ receptor $(\mathrm{C} 5 \mathrm{aR})$. The interaction of chemotactic factor and its receptor stimulates cytoskeletal reorganization, calcium mobilization, and degranulation in heterologous cell types (Firtel and Chung, 2000). The adhesion of leukocytes to vascular endothelial cells is initiated by selection interaction, followed by the interaction of leukocyte integrin of the CD18 complex on the surface of phagocytes with adhesion molecule on endothelial cells (Beutler, 2004). Phagocytosis of microorganism triggers superoxide radical $\left(\mathrm{O}_{2}^{-}\right)$generation and release of reactive oxygen species (ROS) such as hydroxyl radical, hypochlorous acid $(\mathrm{HOCl})$, and chloramines through the activity of myeloperoxidase (MPO). Besides, macrophages are involved in the release of nitric oxide (NO) by inducible nitric oxide synthase (iNOS) (Bogdan, 2001).

Macrophages also modulate adaptive immunity by presenting antigen to CD4 T cells through major histocompatibility complex (MHC) class II antigen. CD4 T cells perform their functions by four subpopulations, which include Th-1, Th-2, Th-17, and CD4 T regulatory (Treg) cells (Chapel et al., 2006). Th cells help B cells develop into plasma cells which can produce antibody and also activate $\mathrm{T}$ cells to become activated cytotoxic $\mathrm{T}$ cells (Beutler, 2004; Luckheeram et al., 2011). Several cytokines also play essential roles in immune response, which consist of proinflammatory cytokines such as tumor necrosis factor-alpha (TNF- $\alpha$ ), interleukin 1 (IL-1), IL-6, IL-11, IL-8, and antiinflammatory cytokines or cytokines inhibitor such as IL-4, IL-10, and IL-13. Cytokines as intercellular messenger molecules have several functions, and these include stimulating phagocyte migration and coordinating early responses of monocytes, macrophages, dendritic cells, and lymphocytes during inflammatory states (Shaikh, 2011). The release of proinflammatory cytokines is regulated by nuclear factor-kappa B (NF-KB) and mitogen-activated protein kinase (MAPK) pathways (Beyaert et al., 2013). Defects or malfunctions in the immune system can cause disorders of the immune system. Inappropriate reaction to self-antigen is known as autoimmunity such as myasthenia gravis, type 1 diabetes (T1D), systemic lupus erythematosus, Graves' disease, celiac disease, pernicious anemia, rheumatoid arthritis, and multiple sclerosis. Overactive immune response is known as hypersensitivity reactions, while ineffective immune response is known as immunodeficiency (Zhernakova et al., 2009; Warrington et al.,
2011; Beyaert et al., 2013). The diseases which cause the body's immune system to attack the small intestine has affected 1 in 133 people in the United States (Rattue, 2012). A review on incidence and prevalence of Crohn's disease in several countries reported a gradual increase in incidence and prevalence of this disease. In Malaysia, a study during 2001-2003 showed an increase of prevalence especially among Indians, compared to Chinese and Malay populations. Meanwhile, in Singapore, a study showed that majority patients were Chinese, and there was a trend of increased of prevalence (Economou et al., 2009). Therefore, modulation of the immune response is required in the management and treatment of diseases due to immune system dysfunction (Geetha et al., 2005).

The treatment of inflammatory and immune-related diseases due to defects or disorders of the immune system necessitates modulation of the immune response. Immunomodulation is the process of modifying an immune response by administration of a drug or compound, while immunomodulators are substances which are used to modulate the components of the immune system (Patil et al., 2012). There are several chemical immunomodulators available in the market, that is, prednisone, hydrocortisone, and dexamethasone, which have been used to treat numerous inflammatory diseases. Recombinant proteins have emerged as one important drug to treat cancer, immunodeficiency, and infectious diseases. Cyclosporin A, a microbial peptide, is the most widely used immunosuppressant in transplant rejection treatment (Elgert, 2009). Unfortunately, most of these commercial drugs have side effects. Gastric and intestinal mucosal damage are the commonest adverse effects of NSAIDS. Corticosteroids, an immunosuppressive drug, show various side effects, such as reduced bone marrow and increased skin fragility. Cyclosporin A exhibited toxicities and side effects including nephrotoxic activity and gingival hyperthrophy. Therefore, safer and more effective drugs are required as alternatives. Natural products remain one of the important sources of new and safe antiinflammatory agents (Elgert, 2009).

In an effort to investigate for safer drugs, ethnopharmacological information can be used to provide preliminary data in the search for new drugs. It can be an indicator of pharmacological activity of natural products that could be further investigated for their mechanisms of action in cellular, animal, and human studies (Flores, 2017). Among them, some therapeutic activities of plant extracts or compounds have been proposed to be due to their effects on the immune system. Many plants of the genus Curcuma, especially C. longa, $C$. zanthorrhiza, C. amada, C. mangga, C. aeruginosa, and C. zedoaria, were reported to modulate the immune functions and possessed a variety of immunomodulatory effects. The strong immunomodulatory activity of these plants was due to their bioactive compounds as their main constituents. Curcuminoids, particularly curcumin, have been reported as the major components of plants in Curcuma species. Besides, other compounds, such as xanthorrhizol, have been reported to be present in other Curcuma species. A number of reviews on the phytochemistry, and biological and pharmacological activities of the genus Curcuma have been published recently (Rajkumari and 

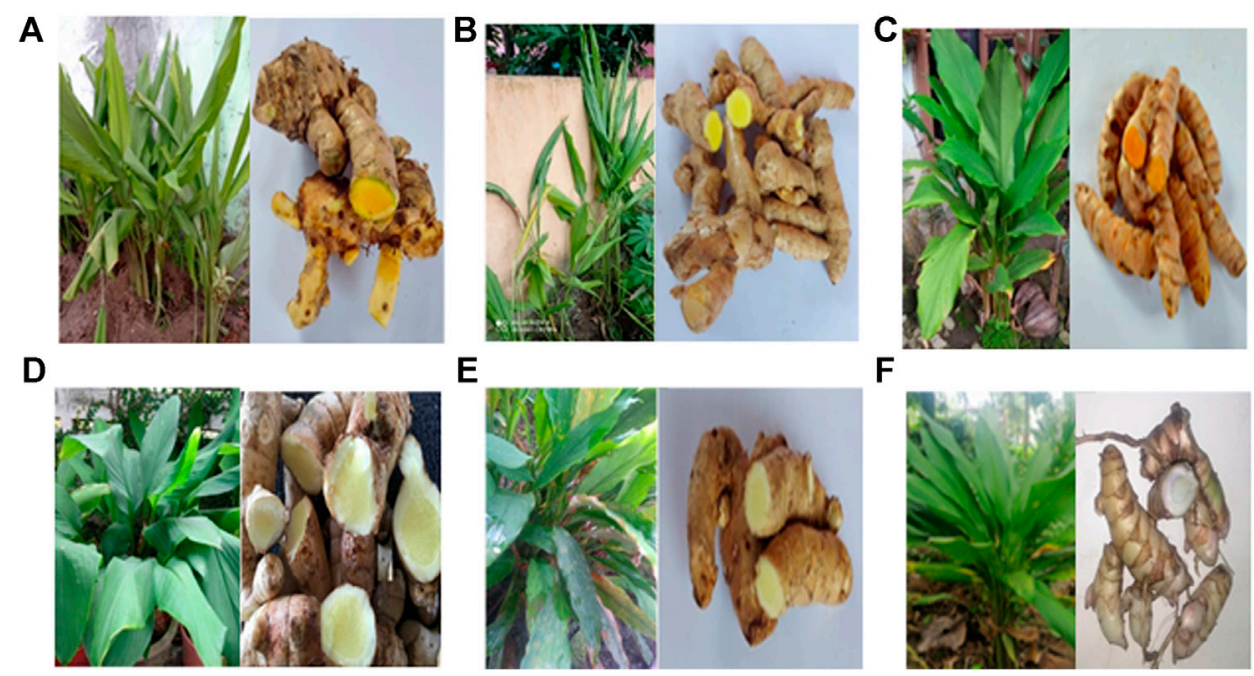

FIGURE 1 | Plants and rhizomes of Curcuma species. (A) Cucuma zanthorrhiza, (B) Curcuma mangga, (C) Curcuma longa, (D) Curcuma amada (Artfire, 2016; Snapdeal, 2020), (E) Curcuma zedoaria, and (F) Curcuma aeruginosa.

Sanatombi, 2017; Sun et al., 2017; Dosoki and Setzer, 2018; Chanda and Ramachandra, 2019; Kaliyadasa and Samarasinghe, 2019; Kavitha and Mahadevi, 2020; USDA, 2021). However, there is either no or little and unconcise reports on the immunomodulatory effects of genus Curcuma and their bioactive molecules in these articles. In this review, we elaborated the ability of C. longa L., C. zanthorrhiza Roxb., C. mangga Valeton \& Zijp, C. aeruginosa Roxb., C. zedoaria (Christm.) Roscoe, and C. amada Roxb. and their bioactive metabolites to modulate the immune response in different lineages of the immune system.

\section{METHODS}

This comprehensive review was based on updated scientific databases on six major Curcuma species, namely, C. longa, C. zanthorrhiza, C. manga, C. aeruginosa, C. zedoaria, and C. amada. Databases were scanned from January 2000 until December 2020 for animal, in vitro, and clinical studies. A systematic search of databases with the use of the keywords "curcuma AND immune system," "curcumin AND immune system," and each species of Curcuma genus, such as "Curcuma mangga AND immune system," "Curcuma longa AND immune system," was carried out. Only published data were included in this study; meanwhile, references without title in English were excluded. Literature search has been carried out extensively to gather data, involving use of published scientific reports in Frontiers, the Science Direct, Scopus, Google Scholar, the Institute for Scientific Information (ISI)-Web of Science, Pub Med, Wiley Online Library, Elsevier, Springer, Taylor and Francis, ACS Publications Today, and other references over the past two decades. The gathered data on the immunomodulating effects of the Curcuma species were critically analyzed, and future strategies and appropriate perspectives for the plants as a source of new natural immunomodulators were discussed.

\section{TAXONOMY AND DISTRIBUTION}

Curcuma L. is one of the largest genera in the family of Zingiberaceae, and there are approximately 100 accepted Curcuma species. It is found throughout tropical Asia from India to South China, Southeast Asia, Papua New Guinea, and northern Australia (Dosoky and Setzer, 2018). The word "curcuma" is derived from the Arabic word "kurkum," which means yellow color (Kaliyadasa and Samarasinghe, 2019). Curcuma species are originated from the Indo-Malayan region and widespread in Asia, Africa, and Australia (Sasikumar, 2005). Figure 1 shows the Curcuma species: C. longa, C. zanthorrhiza, C. amada, C. mangga, C. aeruginosa, and C. zedoaria that are discussed in this review. The rhizomes of these plants are widely utilized in traditional medicine and as spices, food flavors, colorants, cosmetics, and perfumery. C. longa Linn (syn. Curcuma domestica Val.) is native to tropical South Asia, but it has been found throughout tropical areas (Li et al., 2011), such as Cambodia, China, India, Nepal, Indonesia, Madagascar, Malaysia, the Philippines, and Vietnam (Yadav and Tarun, 2017). It is commonly called as turmeric (Li et al., 2011; HMPC, 2017; Rajkumari and Sanatombi, 2017) and the Golden Spice of India (Yadav and Tarun, 2017). C. longa has been associated to the Indian culture for nearly 4000 years and probably reached China by $700 \mathrm{AD}$, East Africa by $800 \mathrm{AD}$, and West Africa by $1200 \mathrm{AD}$ (Yadav and Tarun, 2017). C. longa has a specific name in some regions, namely, Haridra (Sanskrit, Ayurvedic), Jianghuang (Chinese), Kyoo or Ukon (Japanese) (HMPC, 2017), kurkum (Arabic), and haldi (Hindi and Urdu) (Dosoky and Setzer, 2018). C. longa has yellow-white flowers, $10-15 \mathrm{~cm}$ of stalk length, the seeds are brown ovoid, the plant grows upright, and part used for 
spices and medicine is the rhizome (Tung et al., 2019). C. zanthorrhiza is native to Indonesia (Rajkumari and Sanatombi, 2017), and it has been established by the Food and Drug Supervisory Agency (BADAN POM) as one of the leading medicinal plants (Ervintari et al., 2019). It is known as temu lawak (Dewi et al., 2012) and Java turmeric (Kim M-B et al., 2014; Astana et al., 2018), and distributed in Southeast Asia. It has been grown in Thailand, the Philippines, Sri Lanka, and Malaysia (Oon et al., 2015). It is grown simply to produce rhizomes which are commonly used in folk medicine (Wahono et al., 2017b). It is an ethnomedicinal plant from Indonesia and Malaysia (Kim M-B et al., 2014). It has 2-m tall erect pseudostems (Rajkumari and Sanatombi, 2017) and is generally cultivated in village home gardens. The rhizomes smell balmy and taste bitter (Ilene et al., 2020). C. zanthorrhiza has been used as an active ingredient in cosmetic and hygienic products in Germany and the Netherlands (Drugbank, 2021).

C. amada is widely distributed in Myanmar, and in southern and eastern India. Apart from Myanmar, C. amada is also distributed in the tropics of Asia to Africa and Australia. It is widely cultivated in West Bengal, Gujarat, Tamil Nadu, and the northeastern states of India (Sasikumar, 2005). It has the resemblance with ginger (Zingiber officinale) but imparts a raw mango (Mangifera indica) flavor (Policegoudra et al., 2011). Thereby, it is usually known as mango ginger due to its mango flavor. The flavor has been attributed to the presence of cis-ocimene and car-3-ene (Ayodele et al., 2018). C. amada rhizomes are fleshy, buff colored, $5-10 \mathrm{~cm}$ long, and $2-5 \mathrm{~cm}$ in diameter (Artfire, 2016; Policegoudra et al., 2011; Snapdeal, 2020). C. aeruginosa is an endemic species in Myanmar, but it is also distributed in West Bengal and Kerala (Rajkumari and Sanatombi, 2017). C. aeruginosa is also an ethnomedicinal plant in Indonesia, Malaysia, Thailand, Northern Australia, and Papua New Guinea (Sulfianti et al., 2019). It is commonly known as Kali Haldi (in India) and has a deep-blue or bluish-black colored cortex with pungent odor. In Indonesia, C. aeruginosa is known as Temu Ireng (Choudhury et al., 2013; George and Britto, 2015), and in English, it is known as pink and blue ginger (Sulfianti et al., 2019), temu hitam in Malaysia, and waan-maha-mek in Thailand. It is a perennial herb derived from Burma and spread to tropical countries in Malaysia, Thailand, India, and Indonesia (Dosoky and Setzer, 2018). C. zedoaria, known as white turmeric, is a perennial herb with perpendicular pseudostem and fleshy roots. It is a native plant from Bangladesh, India, and Sri Lanka (Lobo et al., 2009), but it is a critically threatened species in Bangladesh and India (Anisuzzaman et al., 2008). It is known by several names in India, and the most common are Krachura (Sanskrit), Gandamatsi (Hindi), and Sutha (Bengali) (Lobo et al., 2009). In China, it is generally called Ezhu (Lee et al., 2019). C. zedoaria is widely cultivated in subtropical regions (Southeast Asia, Thailand, Indonesia, Japan, and China). From outside, $C$. zedoaria looks like ginger, but inside, it looks like turmeric (Dosoky and Setzer, 2018). C. zedoaria rhizome has dark orange-fleshed tubers (Rahayu et al., 2020). C. mangga rhizome is commonly known as mango turmeric as it has the mango-like smell as in C. amada. It is a perennial herb with $30-110 \mathrm{~cm}$ of stem height. It is native from Java (Rajkumari and
Sanatombi, 2017). It is distributed in most tropical countries such as Indonesia, Thailand, and Malaysia (Hong et al., 2016).

\section{ETHNOPHARMACOLOGICAL USES}

C. longa is traditionally used as an antioxidant, antiinflammatory, antidiabetic, hepatoprotective, and anticarcinogenic agent (Alsahli et al., 2018). It is well known as ethnomedicinal plant and used in different traditional systems in the world. In traditional medicine in Nigeria, C. longa is also used as an wound-healing agent (Adeshina et al., 2017). In Nepal, C. longa is applied as an anthelmintic, a tonic and blood purifier as well as for the treatment of Jaundice and liver disorder. In Peru, C. longa juice commonly known as Shapi natiyu is applied for the treatment of bronchitis and malaria. In Colombia, it is used for circulatory stimulant, healing wounds, liver cleaning, immune system booster, thrombosis, indigestion, diabetes, high cholesterol, and kidney infection (Ayati et al., 2019). The Ayurvedic Pharmacopoeia of India documented that C. longa is used as tonic, stomachic, and carminative. In Chinese Pharmacopoeia, C. longa has a potential for eliminating blood stasis, stimulating menstruation discharge, and relieving pain (Yue et al., 2010). In Pakistan traditional medicine, C. longa is used as a wound-healing agent and for the treatment of pimples. In Butanese folk medicine, it is known as Yung-ba and applied as tonic, antidote, antiseptic, anti-inflammatory, and as a good preservative (Ayati et al., 2019). C. zanthorrhiza is traditionally used for wound healing, as anti-inflammatory and anticarcinogecic agent, and for lowering of serum cholesterol levels (Kim et al., 2007) and booster immunity by Javanese (Setyati et al., 2019). In Malaysia, it is traditionally used to treat skin inflammation, rheumatism, stomach and liver disorders, and hepatitis (Kim M-B et al., 2014). In Ayurveda, C. amada is usually used for inflammation, asthma, bronchitis, biliousness, and skin disease (Policegoudra et al., 2006). The rhizomes are usually used for anorexia, dyspepsia, chronic ulcers, pruritus, gout, and inflammations (Thokchom and Phucho, 2015). Traditionally, C. amada is used for inflammation, stomach and skin diseases, cough, and rheumatism in Myanmar (Win et al., 2017). C. aeruginosa is used to booster immunity by Javanese (Setyati et al., 2019). It is used traditionally in Indonesia for gastrointestinal disease, and as antimicrobial and anti-inflammatory agents (Sulfianti et al., 2019). C. zedoaria is commonly known as white turmeric, and it is widely used as a traditional medicine in Indonesia (Putri, 2014; Aristyani et al., 2018), China and Japan (Kim et al., 2001), and India (Nan et al., 2014). C. zedoaria is traditionally used for treating cancer (Dutta, 2015) and also used as a traditional remedy to promote blood circulation in Korea and Japan (Kim et al., 2001). C. zedoaria is used to treat flatulent colic, hepatocirrhosis, and cancer in traditional Chinese medicine. It is also used to treat blood stagnation syndromes and for promoting menstruation (Carvalho et al., 2010). C. mangga is highly valued in Indonesian folk medicine for its healing properties in the treatment of stomach disorders, fever, and cancer-related diseases (Malek et al., 2011). 


\section{PHYTOCHEMISTRY}

Plants from the genus Curcuma L. have been intensively studied for their phytochemical contents and bioactivity due to their tremendous ethnopharmacological and therapeutic potentials. There are recent reviews on the phytochemistry, and biological and pharmacological activities of Curcuma species (Rajkumari and Sanatombi, 2017; Dosoki and Setzer, 2018; Chanda and Ramachandra, 2019; Kavitha and Mahadevi, 2020; USDA, 2021). Phytochemical analysis has revealed that Curcuma species are made up mainly of terpenoids, flavonoids, phenolic compounds, organic acids, anthocyanin, tannins, and inorganic compounds. Until now, phytochemical studies on 32 Curcuma species have isolated and identified a total of 719 compounds, which include 529 terpenoids, 15 flavonoids, 102 diphenylalkanoids, 19 phenylpropene derivatives, 3 alkaloids, 7 steroids, and 44 other types of compounds (Sun et al., 2017). The phytochemical content of $C$. longa has been extensively investigated, and more than 235 compounds have been identified in the rhizome, which are mainly polyphenols and terpenoids. The major group of polyphenols is curcuminoids, which may contain up to $80 \%$ of curcumin, and other two are demethoxycurcumin and bisdemethoxycurcumin. In total, there are 109 sesquiterpenes, 68 monoterpenes, 22 diarylheptanoids and diarylpentanoids, eight phenylpropene and other phenolic compounds, five diterpenes, four sterols, three triterpenoids, two alkaloids, and 14 other compounds (Li et al., 2011). The essential oils of flowers and leaves are mainly made up of monoterpenes, while the root and rhizome oils are dominated by sesquiterpenes. A recent study reported that the average essential oil content in the rhizome was $3.97 \%$, and the major components identified by gas chromatography were ar-turmerone (40\%), $\alpha$-turmerone (10\%), and curlone (23\%) (Guimarães et al., 2020). Xanthorrhizol, a bisabolane-type sesquiterpenoid compound, is the major compound of $C$. zanthorrhiza. Curcumin, demethoxycurcumin, and bisdemethoxycurcumin are also present in appreciable amounts. Sesquiterpenes of the bisabolene-type and their oxygenated derivatives were reported to comprise more than $92 \%$ of the rhizome oil of C. zanthorrhiza. Xanthorrhizol (32\%) was the most abundant sesquiterpene phenol. $\beta$-Curcumene $(17.1 \%)$, zingiberene $(13.2 \%), \quad \beta$ bisabolol (3.5\%), and ar-curcumene (2.6\%) were the other major components of the oil (Jantan et al., 2012).

Several valuable sesquiterpenoids such as zedoarondiol zedoalactone A, zedoalactone B, curcumenol, isocurcumenol, zedoarol, isofuranodiene, and furanodiene have been isolated from $C$. aeruginosa rhizome. The rhizome oil of this plant was made up mainly of 1, 8-cineol, $\beta$-pinene, camphor, curzerenone, furanodienone, furangermenone, curcumenol, zedoarol, isocurcumenol, and $\beta$-elemene (Jose and Thomas, 2014). C. zedoaria rhizome is rich in sesquiterpenoids which are represented by furanodienone, furanodiene, curzerenone, zedorone, germacrone, curzeone, 13-hydroxy germacrone, curcumenol, curcumenone, dihydrocurdione, zedoaronediol, dihydrocurdione, zedoarol, 13-hydroxygermacrone, curzeone curcumenone, curcumanolide- $\mathrm{A}$, curcumanolide- $\mathrm{B}$, $a$-turmerone, $\beta$-turmerone, epicurzerenone, and curzerene. GC and GC-MS analyses of the rhizome oil revealed the presence of curzerenone (22.3\%) as the major component, together with 1,8cineole, germacrone, cymene, $a$-phellandrene, and $\beta$-eudesmol (Lobo et al., 2009). Based on percent yield, myrcene (88.6\%), ocimene (47.2\%), and ar-turmerone (29.12\%) were reported to be the major chemical constituents of C. amada. Other compounds that were present in appreciable amounts were $(Z)-\beta$-farnesene, guaia-6,9-diene, cis $\beta$-ocimene, cis-hydroocimene, transhydroocimene, $a$-longipinene, a-guaiene, linalool, $\beta$ curcumene, and turmerone (Jatoi et al., 2007).

The presence of these diverse bioactive compounds in the plants contributes to the diverse pharmacological activities. Curcumin, one of the main active ingredients in Curcuma species, has been widely reported for its strong immunomodulating, antioxidant, anti-inflammatory, and antitumor activities. Structure-activity relationship studies have revealed that the presence of different functional entities on the diarylheptanoid structure which include methoxy, phenoxy, and carbon-carbon double bonds was found to be responsible for the antioxidant property. However, the remarkable anti-inflammatory property was associated with the symmetry of the structure and position of substituents along with the number of methoxy groups. In addition, electron-withdrawing substituents and the $\alpha, \beta$-unsaturated carbonyl group were indicated imperative for reactivity (Arshad et al., 2017). Besides the curcuminoids (curcumin, demethoxycurcumin, bisdemethoxycurcumin, and dihydrocurcumin), other compounds from Curcuma spp. with significant activity on the immune system include xanthorrhizol, turmeronol, curdione, curcuzedoalide, curcumenol, and germacrone.

\section{IMMUNOMODULATING PROPERTIES OF CURCUMA SPECIES}

Curcuma species and their bioactive compounds have been much investigated for their various biological and pharmacological activities, including antioxidant, anti-inflammatory, anticancer, hepato-protective, antifungal, antihypertensive, neuroprotective, and immunomodulatory effects through in vitro and in vivo studies. The six Curcuma species and their bioactive compounds discussed in this article have been documented to exhibit various pharmacological activities, particularly via modulation of the immune system. There are in-depth mechanistic studies on the immunomodulating effects of some of these species available in the literature. The immunomodulatory effects of the plant samples on the immune system are critically analyzed, and their underlying mechanisms of action are summarized in Table $\mathbf{1}$.

\section{Curcuma longa L.}

\section{In Vitro Immunomodulating Effect of $C$. longa}

Of all the Curcuma species investigated, the immunomodulatory effects of $C$. longa were the most studied. Interestingly, most experimental studies on the extracts of $C$. longa were carried out using in vivo animal models, and there were few in vitro studies. The 
TABLE 1 | Immunomodulatory activity of some Curcuma species.

\begin{tabular}{|c|c|c|c|c|c|c|c|}
\hline Species & Subjects & $\begin{array}{l}\text { Study } \\
\text { design }\end{array}$ & Preparation & $\begin{array}{l}\text { Immunomodulatory } \\
\text { activities }\end{array}$ & Modulation & $\begin{array}{c}\text { Parameters/ } \\
\text { mediators affected }\end{array}$ & References \\
\hline \multirow[t]{3}{*}{$\begin{array}{l}\text { Curcuma } \\
\text { amada Roxb. }\end{array}$} & Rat PMNs & in vitro & $\begin{array}{l}\text { Ethanol, petroleum } \\
\text { ether, chloroform, and } \\
\text { acetone extracts }\end{array}$ & Phagocytosis activity & $\uparrow$ & Phagocytosis & $\begin{array}{l}\text { Karchuli and } \\
\text { Pradhan (2011) }\end{array}$ \\
\hline & $\begin{array}{l}\text { Sheep RBC-induced } \\
\text { albino Wistar rats }\end{array}$ & in vivo & Ethanol extract & Cellular immunity & $\uparrow$ & $\begin{array}{l}\text { Delayed-type } \\
\text { hypersensitivity } \\
\text { response }\end{array}$ & $\begin{array}{l}\text { Karchuli and } \\
\text { Pradhan (2011) }\end{array}$ \\
\hline & $\begin{array}{l}\text { Sheep RBC induced- } \\
\text { albino Wistar rats }\end{array}$ & in vivo & Ethanol extract & Humoral immunity & $\uparrow$ & Antibody titer & $\begin{array}{l}\text { Karchuli and } \\
\text { Pradhan (2011) }\end{array}$ \\
\hline \multirow{9}{*}{$\begin{array}{l}\text { Curcuma } \\
\text { aeruginosa } \\
\text { Roxb. }\end{array}$} & $\begin{array}{l}\text { Zymosan-stimulated } \\
\text { human PMNs }\end{array}$ & in vitro & Methanol extract & ROS generation & $\downarrow$ & ROS & $\begin{array}{l}\text { Jantan et al. } \\
(2011)\end{array}$ \\
\hline & $\begin{array}{l}\text { Zymosan-stimulated } \\
\text { macrophages of BALB/c } \\
\text { mice }\end{array}$ & in vitro & Methanol extract & ROS generation & $\downarrow$ & ROS & $\begin{array}{l}\text { Jantan et al. } \\
\text { (2011) }\end{array}$ \\
\hline & Human PMNs & in vitro & Methanol extract & PMN chemotaxis & $\downarrow$ & Chemotaxis & $\begin{array}{l}\text { Jantan et al. } \\
(2011)\end{array}$ \\
\hline & Human whole blood & in vitro & Methanol extract & CD18/11a expression & $\downarrow$ & CD18/11a & $\begin{array}{l}\text { Harun et al. } \\
(2015)\end{array}$ \\
\hline & Human whole blood & in vitro & Methanol extract & Phagocytosis activity & $\downarrow$ & Phagocytosis & $\begin{array}{l}\text { Harun et al. } \\
(2015)\end{array}$ \\
\hline & $\begin{array}{l}\text { Lymphocytes of BALB/c } \\
\text { mice }\end{array}$ & in vitro & $\begin{array}{l}\text { Extract by steam } \\
\text { distillation }\end{array}$ & $\begin{array}{l}\text { Counts of } \mathrm{CD}^{+} \text {and } \\
\mathrm{CD}^{+} \text {cells }\end{array}$ & $\uparrow$ & $\mathrm{CD}^{+}$and $\mathrm{CD}^{+}$cells & $\begin{array}{l}\text { Anggriani et al. } \\
(2019)\end{array}$ \\
\hline & $\begin{array}{l}\text { DMBA-induced Wistar } \\
\text { rats }\end{array}$ & in vivo & Ethanol extract & Cytokine release & $\uparrow$ & $\begin{array}{l}\text { TNF- } \alpha, \mathrm{IFN}-\gamma, \mathrm{IL}-2 \text {, } \\
\text { and IL-12 }\end{array}$ & $\begin{array}{l}\text { Sulfianti et al. } \\
\text { (2019) }\end{array}$ \\
\hline & Epinephelus fuscoguttatus & in vivo & $\begin{array}{l}\text { C. aeruginosa, Piper } \\
\text { retrofractum, and C. } \\
\text { zanthorrhiza water } \\
\text { extracts }\end{array}$ & Leukocyte number & $\uparrow$ & Total leukocyte count & $\begin{array}{l}\text { Setyati et al. } \\
(2019)\end{array}$ \\
\hline & Epinephelus fuscoguttatus & in vivo & $\begin{array}{l}\text { C. aeruginosa, Piper } \\
\text { retrofractum, and C. } \\
\text { zanthorrhiza water } \\
\text { extracts }\end{array}$ & Phagocytosis activity & $\uparrow$ & Phagocytic index & $\begin{array}{l}\text { Setyati et al. } \\
(2019)\end{array}$ \\
\hline \multirow[t]{11}{*}{$\begin{array}{l}\text { Curcuma } \\
\text { longa Linn }\end{array}$} & $\begin{array}{l}\text { CMS-induced } \\
\text { Sprague-Dawley rats }\end{array}$ & in vivo & Ethanol extract & Cytokine release & $\downarrow$ & IL-6 and TNF- $\alpha$ & Xia et al. (2006) \\
\hline & Male Sprague-Dawley rats & in vivo & Ethanol extract & Splenic NK cell activity & $\uparrow$ & NK cell & Xia et al. (2006) \\
\hline & Mice & in vivo & Methanol extract & $\begin{array}{l}\text { Adaptive immune } \\
\text { response }\end{array}$ & $\uparrow$ & $\begin{array}{l}\text { Leukocytes number, } \\
\text { antibody titer, spleen } \\
\text { index, and delayed- } \\
\text { type hypersensitivity } \\
\text { response }\end{array}$ & $\begin{array}{l}\text { Kumolosasi et al. } \\
\text { (2018) }\end{array}$ \\
\hline & $\begin{array}{l}\text { Human peripheral blood } \\
\text { mononuclear cells } \\
\text { (PBMCs) }\end{array}$ & in vitro & $\begin{array}{l}\text { Polar fraction of hot } \\
\text { water extract }\end{array}$ & Proliferation response & $\uparrow$ & PBMC viability & Yue et al. (2010) \\
\hline & $\begin{array}{l}\text { Human peripheral blood } \\
\text { mononuclear cells } \\
\text { (PBMCs) }\end{array}$ & in vitro & $\begin{array}{l}\text { Polysaccharide- } \\
\text { enriched fraction at } \\
200 \mu \mathrm{g} / \mathrm{ml}\end{array}$ & $\begin{array}{l}\text { Cytokine gene } \\
\text { expression }\end{array}$ & $\uparrow$ & $\begin{array}{l}\text { GM-CSF, IL-1, IL-5, } \\
\mathrm{IL}-8, \mathrm{IL}-10 \text {, and IL-13 }\end{array}$ & Yue et al. (2010) \\
\hline & $\begin{array}{l}\text { Human peripheral blood } \\
\text { mononuclear cells } \\
\text { (PBMCs) }\end{array}$ & in vitro & $\begin{array}{l}\text { Polysaccharide- } \\
\text { enriched fraction at } \\
400 \text { and } 800 \mu \mathrm{g} / \mathrm{ml}\end{array}$ & Cytokine release & $\uparrow$ & TNF- $\alpha$ and IL-6 & Yue et al. (2010) \\
\hline & $\begin{array}{l}\text { Human peripheral blood } \\
\text { mononuclear cells } \\
\text { (PBMCs) }\end{array}$ & in vitro & $\begin{array}{l}\text { Polysaccharide- } \\
\text { enriched fraction at } \\
800 \mu \mathrm{g} / \mathrm{ml}\end{array}$ & Cytokine release & $\uparrow$ & TGF- $\beta$ & Yue et al. (2010) \\
\hline & $\begin{array}{l}\text { Human peripheral blood } \\
\text { mononuclear cells } \\
\text { (PBMCs) }\end{array}$ & in vitro & $\begin{array}{l}\text { Polysaccharide- } \\
\text { enriched fraction at } \\
800 \mu \mathrm{g} / \mathrm{ml}\end{array}$ & Lymphocyte population & $\uparrow$ & $\mathrm{CD}_{14}^{+}$ & Yue et al. (2010) \\
\hline & $\begin{array}{l}\text { Unstimulated mouse } \\
\text { splenocytes and mouse } \\
\text { macrophage (RAW264.7) } \\
\text { cells }\end{array}$ & in vitro & Water extract & Cytokine release & $\uparrow$ & $\begin{array}{l}\mathrm{NO}, \mathrm{IL}-2, \mathrm{IL}-6, \mathrm{IL}-10 \text {, } \\
\mathrm{IL}-12, \mathrm{IFN}-\gamma, \mathrm{TNF}-\alpha \text {, } \\
\text { and MCP-1 }\end{array}$ & $\begin{array}{l}\text { Chinampudur } \\
\text { et al. (2013) }\end{array}$ \\
\hline & $\begin{array}{l}\text { LPS stimulated mouse } \\
\text { splenocytes }\end{array}$ & in vitro & Water extract & Cytokine release & $\downarrow$ & $\begin{array}{l}\mathrm{NO}, \mathrm{IL}-12, \mathrm{IL}-6 \text {, and } \\
\mathrm{PGE}_{2}\end{array}$ & $\begin{array}{l}\text { Chinampudur } \\
\text { et al. (2013) }\end{array}$ \\
\hline & $\begin{array}{l}\text { Con-A-induced } \\
\text { splenocytes }\end{array}$ & in vitro & Water extract & Cytokine release & $\uparrow$ & $\begin{array}{l}\mathrm{IL}-2 \text { and IFN- } \gamma \\
\text { (Continued o }\end{array}$ & $\begin{array}{l}\text { Chinampudur } \\
\text { et al. (2013) } \\
\text { following page) }\end{array}$ \\
\hline
\end{tabular}


TABLE 1 | (Continued) Immunomodulatory activity of some Curcuma species.

\begin{tabular}{|c|c|c|c|c|c|c|c|}
\hline Species & Subjects & $\begin{array}{l}\text { Study } \\
\text { design }\end{array}$ & Preparation & $\begin{array}{l}\text { Immunomodulatory } \\
\text { activities }\end{array}$ & Modulation & $\begin{array}{c}\text { Parameters/ } \\
\text { mediators affected }\end{array}$ & References \\
\hline & $\begin{array}{l}\text { Con-A-induced } \\
\text { splenocytes }\end{array}$ & in vitro & Water extract & Cytokine release & $\downarrow$ & $\mathrm{IL}-10$ & $\begin{array}{l}\text { Chinampudur } \\
\text { et al. (2013) }\end{array}$ \\
\hline & $\begin{array}{l}\text { LPS-unstimulated and } \\
\text { stimulated mouse } \\
\text { splenocytes }\end{array}$ & in vitro & $\begin{array}{l}\text { Polysaccharide } \\
\text { fraction }\end{array}$ & Lymphocyte proliferation & $\uparrow$ & Splenocytes number & $\begin{array}{l}\text { Chinampudur } \\
\text { et al. (2013) }\end{array}$ \\
\hline & $\begin{array}{l}\text { LPS-stimulated mouse } \\
\text { splenocytes }\end{array}$ & in vitro & $\begin{array}{l}\text { Polysaccharide } \\
\text { fraction }\end{array}$ & Cytokine release & $\uparrow$ & $\| \mathrm{L}-10$ & $\begin{array}{l}\text { Chinampudur } \\
\text { et al. (2013) }\end{array}$ \\
\hline & $\begin{array}{l}\text { LPS-stimulated mouse } \\
\text { splenocytes }\end{array}$ & in vitro & $\begin{array}{l}\text { Polysaccharide } \\
\text { fraction }\end{array}$ & Cytokine release & $\downarrow$ & $\mathrm{IL}_{-12}$ and $\mathrm{PGE}_{2}$ & $\begin{array}{l}\text { Chinampudur } \\
\text { et al. (2013) }\end{array}$ \\
\hline & RAW264.7 macrophages & in vitro & Water extract & $\begin{array}{l}\text { Nitric oxide (NO) } \\
\text { production }\end{array}$ & $\uparrow$ & NO levels & Pan et al. (2017) \\
\hline & Diabetic infected rats & in vivo & Ethanol extract & Total lgE & $\downarrow$ & lgE levels & $\begin{array}{l}\text { Shabana et al. } \\
(2020)\end{array}$ \\
\hline & Diabetic infected rats & in vivo & Ethanol extract & Leukocyte number & $\downarrow$ & $\begin{array}{l}\text { Total leukocyte } \\
\text { count (TLC) }\end{array}$ & $\begin{array}{l}\text { Shabana et al. } \\
(2020)\end{array}$ \\
\hline & Diabetic infected rats & in vivo & Ethanol extract & NO production & $\downarrow$ & NO & $\begin{array}{l}\text { Shabana et al., } \\
2020\end{array}$ \\
\hline & Diabetic infected rats & in vivo & Ethanol extract & Cytokine release & $\downarrow$ & IL-6, TNF-a, and IL-1 $\beta$ & $\begin{array}{l}\text { Shabana et al., } \\
2020\end{array}$ \\
\hline & $\begin{array}{l}\text { LP-BM5 MuLV-induced } \\
\text { mice }\end{array}$ & in vivo & Alcohol extract & Proliferation & $\downarrow$ & $\begin{array}{l}\text { T-cell, B-cell, and NK- } \\
\text { cell }\end{array}$ & $\begin{array}{l}\text { Kim O. K. et al. } \\
(2014)\end{array}$ \\
\hline & $\begin{array}{l}\text { LP-BM5 MuLV-induced } \\
\text { mice }\end{array}$ & in vivo & Alcohol extract & Cytokine imbalance & Prevented & $\begin{array}{l}\text { Th1 (IL-2 and IFN- } \\
\gamma) / T h 2)(\text { IL-4 and } \\
\text { IL-10) }\end{array}$ & $\begin{array}{l}\text { Kim O. K. et al. } \\
(2014)\end{array}$ \\
\hline & C57BL/6 mice & in vivo & $\begin{array}{l}\text { C. longa, Mulberry } \\
\text { leaves, and purple } \\
\text { sweet potato extracts }\end{array}$ & Proliferation & $\downarrow$ & $\mathrm{T}$ cell and $\mathrm{B}$ cell & Yoo et al. (2013) \\
\hline & C57BL/6 mice & in vivo & $\begin{array}{l}\text { C. longa, Mulberry } \\
\text { leaves, and purple } \\
\text { sweet potato extracts }\end{array}$ & Cytokine secretion & $\downarrow$ & $\begin{array}{l}\text { Th } 1 \text { cytokines (IL-2 } \\
\text { and IFN- } \gamma \text { ), Th2 } \\
\text { cytokines (TNF- } \alpha \text { and } \\
\text { IL-10) }\end{array}$ & Yoo et al. (2013) \\
\hline & $\begin{array}{l}\text { LP-BM5 MuLV-infected } \\
\text { mice }\end{array}$ & in vivo & $\begin{array}{l}\text { C. longa and sweet } \\
\text { potato mixture }\end{array}$ & $\begin{array}{l}\text { Messenger RNA (mRNA) } \\
\text { expression }\end{array}$ & $\uparrow$ & $\mathrm{MHC}$ I and $\mathrm{MHC} \|$ & Park et al. (2018) \\
\hline & $\begin{array}{l}\text { LP-BM5 MuLV-infected } \\
\text { mice }\end{array}$ & in vivo & $\begin{array}{l}\text { C. longa and sweet } \\
\text { potato mixture }\end{array}$ & $\begin{array}{l}\text { Population of CD4 } \\
(+) / C D 8(+) T \text { cells }\end{array}$ & $\downarrow$ & $\begin{array}{l}\text { CD4 (+)/CD8 (+) } \\
\text { T cells }\end{array}$ & Park et al. (2018) \\
\hline & $\begin{array}{l}\text { LP-BM5 MuLV-infected } \\
\text { mice }\end{array}$ & in vivo & $\begin{array}{l}\text { C. longa powder and } \\
\text { sweet potato mixture }\end{array}$ & Ig levels & $\downarrow$ & $\lg A, \lg E$, and $\lg G$ & Park et al. (2018) \\
\hline & $\begin{array}{l}\text { Human umbilical vein } \\
\text { endothelial cells (HUVECs) }\end{array}$ & in vitro & Extract & mRNA levels & $\downarrow$ & $\begin{array}{l}\text { NF-kB p65, IL-6, and } \\
\text { TNF- } \alpha\end{array}$ & $\begin{array}{l}\text { Morales et al. } \\
(2012)\end{array}$ \\
\hline & C57BL mice & in vivo & Hot water extract & Cytokines release & $\downarrow$ & $\begin{array}{l}\text { TNF- } \alpha, I L-6 \text {, and IL-6 } \\
\text { m-RNA proteins }\end{array}$ & $\begin{array}{l}\text { Uchio et al. } \\
(2017)\end{array}$ \\
\hline & Fusarium root & in vivo & Aqueous extract & $\begin{array}{l}\text { mRNA of the defense- } \\
\text { related genes }\end{array}$ & $\uparrow$ & $\begin{array}{l}\text { Defensin and } \\
\text { chitinase }\end{array}$ & $\begin{array}{l}\text { Alsahli et al. } \\
(2018)\end{array}$ \\
\hline & Clarias gariepinus & in vivo & Powder & lgM level & $\uparrow$ & $\lg M$ & $\begin{array}{l}\text { Adeshina et al. } \\
\text { (2017) }\end{array}$ \\
\hline & Clarias gariepinus & in vivo & Powder & Enzyme activity & $\uparrow$ & Lysozyme activity & $\begin{array}{l}\text { Adeshina et al. } \\
\text { (2017) }\end{array}$ \\
\hline & Cyprinus carpio & in vivo & Powder & Leukocyte number & $\uparrow$ & $\begin{array}{l}\text { Neutrophils, } \\
\text { lymphocytes, } \\
\text { monocyctes, } \\
\text { eosinophils, and } \\
\text { basophils }\end{array}$ & $\begin{array}{l}\text { Arunkumar et al. } \\
\text { (2016) }\end{array}$ \\
\hline & $\begin{array}{l}\text { Fish green terror } \\
\text { (Andinocara rivulatus) }\end{array}$ & in vivo & Powder & White blood cell number & $\uparrow$ & White blood cells & $\begin{array}{l}\text { Mooraki et al. } \\
\text { (2019) }\end{array}$ \\
\hline & $\begin{array}{l}\text { Nile tilapia (Oreochromis } \\
\text { niloticus) }\end{array}$ & in vivo & Powder & Leukocrit levels & $\uparrow$ & Leukocrit number & $\begin{array}{l}\text { Hassan et al. } \\
(2018)\end{array}$ \\
\hline & M. rosenbergii & in vivo & Powder & Gene expression & $\uparrow$ & Crustin and lysozyme & $\begin{array}{l}\text { Alambra et al. } \\
\text { (2012) }\end{array}$ \\
\hline & Chicks & in vivo & Powder & Lymphocyte percentage & $\uparrow$ & Lymphocytes & $\begin{array}{l}\text { Naderi et al. } \\
(2014)\end{array}$ \\
\hline $\begin{array}{l}\text { Curcuma } \\
\text { zedoaria } \\
\text { Rosc. }\end{array}$ & $\begin{array}{l}\text { LPS-stimulated } \\
\text { RAW264.7 cells }\end{array}$ & in vitro & Methanol extract & NO production & $\downarrow$ & NO & Lee et al. (2019) \\
\hline
\end{tabular}


TABLE 1 | (Continued) Immunomodulatory activity of some Curcuma species.

\begin{tabular}{|c|c|c|c|c|c|c|c|}
\hline Species & Subjects & $\begin{array}{c}\text { Study } \\
\text { design }\end{array}$ & Preparation & $\begin{array}{l}\text { Immunomodulatory } \\
\text { activities }\end{array}$ & Modulation & $\begin{array}{c}\text { Parameters/ } \\
\text { mediators affected }\end{array}$ & References \\
\hline & $\begin{array}{l}\text { LPS-stimulated } \\
\text { RAW264.7 cells }\end{array}$ & in vitro & Methanol extract & $\begin{array}{l}\text { Pro-inflammatory protein } \\
\text { expression }\end{array}$ & $\downarrow$ & iNOS and COX-2 & Lee et al. (2019) \\
\hline & RBL-2H3 cells & in vitro & $\begin{array}{l}\text { Aqueous acetone } \\
\text { extract }\end{array}$ & $\begin{array}{l}\text { Beta-hexosaminidase } \\
\text { release }\end{array}$ & $\downarrow$ & Beta-hexosaminidase & Lobo et al. (2009) \\
\hline & C57BI/6J mice & in vivo & Ethanol extract & Total leukocytes count & $\uparrow$ & Leukocytes & $\begin{array}{l}\text { Carvalho et al. } \\
(2010)\end{array}$ \\
\hline & $\begin{array}{l}\text { L. monocytogenes and } S \text {. } \\
\text { aureus-stimulated } \\
\text { RAW264.7 cells }\end{array}$ & in vitro & Essential oil & Cytokine release & $\downarrow$ & TNF- $\alpha$ & $\begin{array}{l}\text { Huang et al. } \\
(2019)\end{array}$ \\
\hline & $\begin{array}{l}\text { PMA-stimulated } \\
\text { RAW264.7 cells }\end{array}$ & in vitro & $\begin{array}{l}\text { Polysaccharide } \\
\text { fraction }\end{array}$ & Cytokine release & $\uparrow$ & TNF- $\alpha$ & Kim et al. (2001) \\
\hline & $\begin{array}{l}\text { PMA-stimulated } \\
\text { RAW264.7 cells }\end{array}$ & in vitro & $\begin{array}{l}\text { Polysaccharide } \\
\text { fraction }\end{array}$ & NO production & $\uparrow$ & NO & Kim et al. (2001) \\
\hline \multirow{19}{*}{$\begin{array}{l}\text { Curcuma } \\
\text { zanthorrhiza } \\
\text { Roxb. }\end{array}$} & $\begin{array}{l}\text { Zymosan-stimulated } \\
\text { human whole blood }\end{array}$ & in vitro & Methanol extract & ROS generation & $\downarrow$ & ROS & $\begin{array}{l}\text { Jantan et al. } \\
\text { (2011) }\end{array}$ \\
\hline & $\begin{array}{l}\text { Zymosan-stimulated } \\
\text { PMNs }\end{array}$ & in vitro & Methanol extract & ROS generation & $\downarrow$ & ROS & $\begin{array}{l}\text { Jantan et al. } \\
(2011)\end{array}$ \\
\hline & $\begin{array}{l}\text { Zymosan-stimulated } \\
\text { macrophages of BALB/c } \\
\text { mice }\end{array}$ & in vitro & Methanol extract & ROS generation & $\downarrow$ & ROS & $\begin{array}{l}\text { Jantan et al. } \\
\text { (2011) }\end{array}$ \\
\hline & Human PMNs & in vitro & Methanol extract & PMN chemotaxis & $\downarrow$ & Chemotaxis & $\begin{array}{l}\text { Jantan et al. } \\
(2011)\end{array}$ \\
\hline & Human whole blood & in vitro & Methanol extract & Expression of CD18/11a & $\downarrow$ & CD18/11a & $\begin{array}{l}\text { Harun et al. } \\
(2015)\end{array}$ \\
\hline & Human whole blood & in vitro & Methanol extract & Phagocytosis activity & $\uparrow$ & Phagocytosis & $\begin{array}{l}\text { Harun et al. } \\
(2015)\end{array}$ \\
\hline & $\begin{array}{l}\text { Hypercholesterolemic } \\
\text { male Sprague-Dawley rats }\end{array}$ & in vivo & Curcuminoid cider & $\begin{array}{l}\text { IL1 } 1 \beta, \text { TNF } \alpha \text {, and } \\
\text { chemokine gene } \\
\text { expression }\end{array}$ & $\downarrow$ & $\begin{array}{l}\text { IL1 } \beta, \text { TNF } \alpha \text {, and } \\
\text { chemokine }\end{array}$ & $\begin{array}{l}\text { Hardiwati et al. } \\
\text { (2019) }\end{array}$ \\
\hline & $\begin{array}{l}\text { High cholesterol diet male } \\
\text { Sprague-Dawley rats }\end{array}$ & in vivo & Curcuminoid cider & $\begin{array}{l}\text { CD44, ICAM-1, iNOS, } \\
\text { and LOX-1 gene } \\
\text { expression }\end{array}$ & $\downarrow$ & $\begin{array}{l}\text { CD44, ICAM-1, iNOS, } \\
\text { and LOX-1 }\end{array}$ & $\begin{array}{l}\text { Mauren et al. } \\
(2016)\end{array}$ \\
\hline & Human lymphocytes & in vitro & Volatile oil & $\begin{array}{l}\text { Lymphocytes } \\
\text { proliferation }\end{array}$ & $\uparrow$ & Lymphocytes & Miksusanti (2012) \\
\hline & Alcohol-induced mice & in vivo & Ethanol extract & $\begin{array}{l}\text { Lymphocytes } \\
\text { proliferation }\end{array}$ & $\downarrow$ & Lymphocytes & llene et al. (2020) \\
\hline & $\begin{array}{l}\text { High-fat diet-induced } \\
\text { C57BL/6 mice }\end{array}$ & in vivo & Ethanol extract & $\begin{array}{l}\text { Cytokine genes } \\
\text { expression }\end{array}$ & $\downarrow$ & $\begin{array}{l}\text { TNF- } \alpha, I L-6, I L-1 \beta \text {, } \\
\text { and C-reactive } \\
\text { protein (CRP) }\end{array}$ & $\begin{array}{l}\text { Kim M-B et al. } \\
(2014)\end{array}$ \\
\hline & RAW 264.7 cells & in vitro & $\begin{array}{l}\text { Crude polysaccharide } \\
\text { extract }\end{array}$ & $\begin{array}{l}\text { Chemical mediators } \\
\text { release }\end{array}$ & $\uparrow$ & TNF- $\alpha$ and $\mathrm{PGE}_{2}$ & Kim et al. (2007) \\
\hline & RAW 264.7 cells & in vitro & $\begin{array}{l}\text { Crude polysaccharide } \\
\text { extract }\end{array}$ & Oxidative burst & $\uparrow$ & $\mathrm{NO}$ and $\mathrm{H}_{2} \mathrm{O}_{2}$ & Kim et al. (2007) \\
\hline & RAW 264.7 cells & in vitro & $\begin{array}{l}\text { Crude polysaccharide } \\
\text { extract }\end{array}$ & Phosphorylation & $\uparrow$ & $\mid \kappa B \alpha$ & Kim et al. (2007) \\
\hline & $\begin{array}{l}\text { LPS-stimulated human } \\
\text { gingival fibroblast- } 1 \text { cells }\end{array}$ & in vitro & $\begin{array}{l}\text { Crude polysaccharide } \\
\text { extract }\end{array}$ & mRNA levels & $\downarrow$ & $\begin{array}{l}\mathrm{IL}-1 \beta, \mathrm{NF}-\kappa \mathrm{B} \text { p65, } \\
\mathrm{MMP}-2 \text {, and MMP-8 }\end{array}$ & Kim et al. (2018) \\
\hline & HIV/AIDS patients & $\begin{array}{l}\text { Clinical } \\
\text { study }\end{array}$ & $\begin{array}{l}\text { C. zanthorrhiza in } \\
\text { combination with } C \text {. } \\
\text { mangga and } \\
\text { Phyllanthus niruri }\end{array}$ & $\begin{array}{l}\text { Lymphocytes } \\
\text { proliferation }\end{array}$ & Maintained & $\mathrm{CD}^{+}$value & $\begin{array}{l}\text { Astana et al. } \\
(2018)\end{array}$ \\
\hline & $\begin{array}{l}\text { Systemic lupus } \\
\text { erythematosus (SLE) } \\
\text { patients }\end{array}$ & $\begin{array}{l}\text { Clinical } \\
\text { study }\end{array}$ & $\begin{array}{l}\text { C. zanthorrhiza } \\
\text { supplementation with } \\
\text { vitamin D3 }\end{array}$ & Cytokine release & $\begin{array}{l}\text { No significant } \\
\text { difference } \\
\text { reduction }\end{array}$ & $\mathrm{IL}-6$ & $\begin{array}{l}\text { Wahono et al. } \\
\text { (2017a) }\end{array}$ \\
\hline & $\begin{array}{l}\text { Systemic lupus } \\
\text { erythematosus (SLE) } \\
\text { patients }\end{array}$ & $\begin{array}{l}\text { Clinical } \\
\text { study }\end{array}$ & $\begin{array}{l}\text { C. zanthorrhiza } \\
\text { supplementation with } \\
\text { vitamin D3 }\end{array}$ & Cytokine release & $\begin{array}{l}\text { No significant } \\
\text { difference } \\
\text { reduction }\end{array}$ & $\mathrm{IL}-17$ & $\begin{array}{l}\text { Wahono et al. } \\
\text { (2017b) }\end{array}$ \\
\hline & $\begin{array}{l}\text { Systemic lupus } \\
\text { erythematosus (SLE) } \\
\text { patients }\end{array}$ & $\begin{array}{l}\text { Clinical } \\
\text { study }\end{array}$ & Powder & Cytokine release & $\downarrow$ & TNF- $\alpha$ & $\begin{array}{l}\text { Setiawati et al. } \\
(2017)\end{array}$ \\
\hline
\end{tabular}


TABLE 1 | (Continued) Immunomodulatory activity of some Curcuma species.

\begin{tabular}{|c|c|c|c|c|c|c|c|}
\hline Species & Subjects & $\begin{array}{c}\text { Study } \\
\text { design }\end{array}$ & Preparation & $\begin{array}{l}\text { Immunomodulatory } \\
\text { activities }\end{array}$ & Modulation & $\begin{array}{c}\text { Parameters/ } \\
\text { mediators affected }\end{array}$ & References \\
\hline \multirow[t]{14}{*}{$\begin{array}{l}\text { Curcuma } \\
\text { mangga Val. }\end{array}$} & Swiss albino mice & in vivo & $\begin{array}{l}\text { Ethanol extract and its } \\
\text { fraction (hexane, } \\
\text { chloroform, ethyl } \\
\text { acetate, and aqueous } \\
\text { fractions) }\end{array}$ & Paw and ear edema & $\downarrow$ & Paw and ear volume & $\begin{array}{l}\text { Ruangsang et al. } \\
(2010)\end{array}$ \\
\hline & $\begin{array}{l}\text { LPS and IFN } \gamma \text {-induced } \\
\text { RAW264.7 macrophage } \\
\text { cells }\end{array}$ & in vitro & Methanol extract & NO production & $\downarrow$ & NO & Abas et al. (2006) \\
\hline & $\begin{array}{l}\text { LPS-stimulated } \\
\text { RAW264.7 macrophage } \\
\text { cells }\end{array}$ & in vitro & $\begin{array}{l}\text { Ethanol extract and } \\
\text { chloroform, hexane, } \\
\text { and ethyl acetate } \\
\text { fractions }\end{array}$ & NO production & $\downarrow$ & NO & $\begin{array}{l}\text { Kaewkroek et al. } \\
\text { (2009) }\end{array}$ \\
\hline & $\begin{array}{l}\text { Zymosan-stimulated } \\
\text { human whole blood }\end{array}$ & in vitro & Methanol extract & ROS inhibitory activity & $\downarrow$ & ROS & $\begin{array}{l}\text { Jantan et al. } \\
(2011)\end{array}$ \\
\hline & $\begin{array}{l}\text { Zymosan-stimulated } \\
\text { human PMNs }\end{array}$ & in vitro & Methanol extract & ROS inhibitory activity & $\downarrow$ & ROS & $\begin{array}{l}\text { Jantan et al. } \\
(2011)\end{array}$ \\
\hline & $\begin{array}{l}\text { Zymosan-stimulated } \\
\text { macrophages of BALB/c } \\
\text { mice }\end{array}$ & in vitro & Methanol extract & ROS inhibitory activity & $\downarrow$ & ROS & $\begin{array}{l}\text { Jantan et al. } \\
(2011)\end{array}$ \\
\hline & Human PMNs & in vitro & Methanol extract & PMN chemotaxis & $\downarrow$ & Chemotaxis & $\begin{array}{l}\text { Jantan et al. } \\
(2011)\end{array}$ \\
\hline & Human whole blood & in vitro & Methanol extract & Expression of CD18/11a & $\downarrow$ & CD18/11a & $\begin{array}{l}\text { Harun et al. } \\
(2015)\end{array}$ \\
\hline & Human whole blood & in vitro & Methanol extract & Phagocytosis activity & $\uparrow$ & Phagocytosis & $\begin{array}{l}\text { Harun et al. } \\
(2015)\end{array}$ \\
\hline & Mice & in vivo & $\begin{array}{l}n \text {-Hexane, ethyl } \\
\text { acetate, and ethanol } \\
\text { extracts }\end{array}$ & Phagocytosis activity & $\uparrow$ & Phagocytosis & $\begin{array}{l}\text { Yuandani and } \\
\text { Suwarso } \\
\text { (2017b); } \\
\text { Yuandani et al. } \\
\text { (2019) }\end{array}$ \\
\hline & $\begin{array}{l}\text { Bovine RBC-stimulated } \\
\text { mice }\end{array}$ & in vivo & Ethanol extract & Humoral immunity & $\uparrow$ & Antibody titer & $\begin{array}{l}\text { Yuandani et al. } \\
\text { (2018) }\end{array}$ \\
\hline & $\begin{array}{l}\text { Bovine RBC-stimulated } \\
\text { mice }\end{array}$ & in vivo & Ethanol extract & Cellular immunity & $\uparrow$ & $\begin{array}{l}\text { Delayed-type } \\
\text { hypersensitivity } \\
\text { response }\end{array}$ & $\begin{array}{l}\text { Yuandani et al. } \\
\text { (2018) }\end{array}$ \\
\hline & $\begin{array}{l}\text { Doxorubicin-induced } \\
\text { immunosuppressive rats }\end{array}$ & in vivo & Ethanol extract & Humoral immunity & $\uparrow$ & Antibody titer & $\begin{array}{l}\text { Yuandani et al. } \\
\text { (2020) }\end{array}$ \\
\hline & $\begin{array}{l}\text { Doxorubicin-induced } \\
\text { immunosuppressive rats }\end{array}$ & in vivo & Ethanol extract & Cellular immunity & $\uparrow$ & $\begin{array}{l}\text { Delayed-type } \\
\text { hypersensitivity } \\
\text { response }\end{array}$ & $\begin{array}{l}\text { Yuandani et al. } \\
\text { (2020) }\end{array}$ \\
\hline
\end{tabular}

$\uparrow$, increase.

$\downarrow$, decrease.

followings are reports on the few in vitro studies that have been carried out to evaluate the immunomodulating effects of C. longa. $C$ longa fermented by Aspergillus oryzae (FCL) exhibited immunomodulatory effects in RAW 264.7 cells. The different extracts of FLC on phagocytic activity, TNF- $\alpha$, NO production, NK cell activity, and mRNA expression of LP-BM5 eco displayed the following results: hot water and $20 \%$ ethanol extracts increased the phagocytic activity, but there was no significant change in the production of NO relative to the control. There was also suppression of mRNA expression of LP-BM5 eco in FCL extracts and a four-fold increase in NK cell cytotoxity relative to the control group, especially in the $20 \%$ ethanol extract treatment group. However, TNF- $\alpha$ was significantly increased by the addition of FCL extracts (Yoo et al., 2014). Curcuminoid extract from $C$. longa has been reported to modulate TNF- $\alpha$ and IL- 6 at protein and gene levels in adipocytes in vitro (Hardiwati et al., 2019). C. longa decreased mRNA levels of NF- $\kappa$ B p65, IL-6, and TNF- $\alpha$ at $2.5-5 \mathrm{mg} /$ L in LPS-induced human umbilical vein endothelial cells (HUVEC) (Morales et al., 2012). The polysaccharide extract isolated from $C$. longa was reported to possess immunostimulatory activities. Investigation of the polar fractions of $C$. longa hot water extract displayed that the extract stimulated PBMC proliferation using the [methyl-3H]-thymidine incorporation assay. Furthermore, its polysaccharide-enriched fraction at $200 \mu \mathrm{g} / \mathrm{ml}$ enhanced the cytokine expression (IL-1, IL-5, IL-8, IL-10, IL-13, and GM-CSF) detected by semiquantitatively using the antibody-based RayBio human cytokine array. However, the fraction at $200 \mu \mathrm{g} / \mathrm{ml}$ did not significantly enhance TNF- $\alpha$, IFN- $\gamma$, TGF- $\beta$, and IL- 6 productions. The production of IL- 6 and TNF- $\alpha$ was only enhanced after treatment with the fraction at the higher doses of 400 and $800 \mu \mathrm{g} / \mathrm{ml}$, respectively. The polysaccharide fraction at $800 \mu \mathrm{g} / \mathrm{ml}$ stimulated TGF- $\beta$ release and CD14+ lymphocyte and 
population. However, the CD4+/CD8+ ratio was not altered after administration with polysaccharide fraction (Yue et al., 2010). In a related study, the immunostimulant and anti-inflammatory effects of C. longa aqueous extract and its polysaccharide fractions in the presence and absence of mitogens were determined. The extract enhanced splenocyte proliferation in unstimulated and LPS or concanavalin A-stimulated cells. The extract increased the levels of IL-2, IL-10, NO, IL-6, IL-12, TNF- $\alpha$, IFN- $\gamma$, and MCP-1 in the absence of mitogen. Interestingly, $C$. longa extract decreased the levels of IL-12, IL-6, NO, and PGE-2 in LPS-stimulated cells, while TNF- $\alpha$, IL-10, and MCP-1 levels were not altered. In contrast, the extract stimulated IL- 2 and IFN- $\gamma$ production but decreased IL-10 production from Con-A-induced splenocytes. Furthermore, its polysaccharide fraction showed stimulatory activity on lymphocyte proliferation in the absence or presence of LPS. The levels of IL-10 were increased, but the levels of IL-12 and PGE-2 were decreased after treatment with C. longa in LPS-stimulated cells (Chinampudur et al., 2013). In another study, a C. longa root aqueous extract standardized to a minimum of $20 \%$ of polysaccharides ukonan $\mathrm{A}, \mathrm{B}, \mathrm{C}$, and $\mathrm{D}$ was shown to stimulate NO production in RAW264.7 macrophages (Pan et al., 2017).

\section{In Vivo Immunomodulating Effect of C. longa}

Most immunomodulating studies were carried out using aqueous and alcoholic extracts. The ethanol extract of C. longa was reported to suppress immune function, and behavioral and neuroendocrine alterations in a rat chronic mild stress (CMS) model. The enhancement of cytokine level (TNF- $\alpha$ and IL-6) activity and NK cell activity inhibition in the CMS-induced rat in splenocytes were reversed by administration of $35 \mathrm{mg} / \mathrm{kg}$ of $C$. longa ethanol extract and $7 \mathrm{mg} / \mathrm{kg}$ of fluoxetine as a control. The putative antidepressant properties of the extract were due to suppressive effects on cytokine biosynthesis. However, the extract increased the IL-6 level in the nonstress group, but there was no significant difference as compared with those of the normal group and caused a slight but no significant decrease in TNF- $\alpha$ levels. Although the extract enhanced splenic NK cell activity in CMStreated rats, the NK cell activity of nonstressed rat did not change after treatment with C. longa (Xia et al., 2006). In another study, treatment with $C$. longa methanol extract with a single dose of $200 \mathrm{mg} / \mathrm{kg}$ for 14 days in mice stimulated innate and adaptive immunity. The effect of the extract on adaptive immunity was investigated by immunizing and challenging the mice with sheep red blood cells (sRBCs) on days 7 and 14, respectively. C. longa enhanced the adaptive immunity by increasing leukocyte number, antibody titer, spleen index, and delayed-type hypersensitivity response (Kumolosasi et al., 2018). However, the results of this study are preliminary as different doses of the extract need to be used to determine a dose-response relationship and the optimal dose for efficacy.

A previous study reported that treatment with C. longa in diabetic rats infected with Staphylococcus aureus resulted in a decrease of IgE, total leukocyte number (TLC), NO, and cytokine production (IL-6, IL-1 $\beta$, and TNF- $\alpha$ ). The results indicated that there was improvement of immune function by reducing levels of pro-inflammatory cytokines in the diabetic rats (Shabana et al., 2020). It was reported that $20 \%$
C. longa alcohol extract suppressed the increase of liver weights, lymph node, and spleen, and reduction of proliferation of $\mathrm{T}$ and $B$ cells and NK cell activity stimulated by murine leukemia viruses-induced murine acquired immunodeficiency syndrome (AIDS) infection. Moreover, the extract suppressed Th1/Th2 (IL-2, IFN- $\gamma /$ IL-4, and IL-10) cytokine imbalance and proinflammatory cytokine production (Kim O-K et al., 2014). This is in agreement with another study which showed that a diet consisted of C. longa; mulberry leaves and purple sweet potato extracts have the ability to prevent splenomegaly and lymphadenopathy induced by retrovirus, decrement of B- and $\mathrm{T}$-cell proliferation, as well as reduction of Th 1 cytokine (IFN- $\gamma$ and IL-2) release. It also reduced Th2 cytokine (TNF- $\alpha$ and IL10) release (Yoo et al., 2013). Moreover, C. longa alone and in combination with purple sweet potato inhibited LP-BM5 murine leukemia virus (MuLV)-induced lymphadenopathy. The mixture of $C$. longa and purple sweet potato at the doses of 2 and $5 \mathrm{~g} / \mathrm{kg}$ body weight increased the mRNA expression of MHC I and II as compared to those of the infected control group. The mixture at $5 \mathrm{~g} / \mathrm{kg}$ body weight decreased the population of $\mathrm{CD}^{+} \mathrm{T}$ cells as compared to the infected control group, and also, the population of $\mathrm{CD}^{+} \mathrm{T}$ cells was lower than that of the normal group. Moreover, the extracts also affected T- and B-cell proliferation. The levels of Th1-type cytokines (IL-12 and IL-15) were enhanced after treatment by the mixture; meanwhile, Th2-type cytokine (IL-4, IL-10, IL-6, and TNF- $\alpha$ ) production was significantly decreased as compared to the infected control group. In addition, the mixture at the doses of 2 and $5 \mathrm{~g} / \mathrm{kg}$ decreased the levels of IgA, IgE, and IgG. Besides, C. longa alone or in mixture enhanced the phagocytosis activity of LP-BM5 MuLV-infected mice (Park et al., 2018). C. longa hot water extract protected the C57BL mice liver from acute injury induced by ethanol at $3 \mathrm{~g} / \mathrm{kg}$. The hepatic injury caused an increase in TNF- $\alpha$, IL-6, and IL-6 $\mathrm{m}$-RNA proteins. However, an increase in these proteins was not found in mice treated with hot water extract of $C$. longa $30 \mathrm{~min}$ before induction (Uchio et al., 2017). C. longa aqueous extract has been evaluated for its immunotherapeutic and hepatoprotective activities in $\mathrm{CCl}_{4}$ intoxicated Swiss albino mice. The aqueous extract reduced the levels of bilirubin and transaminase enzymes (SGOT and SGPT) in mice. Treatment with $\mathrm{CCl}_{4}$ resulted in liver damage and reduced nonspecific host-response parameters such as NO and MPO release, phagocytosis, intracellular killing capacity of peritoneal macrophages, and morphological alteration. Treatment with the extract also significantly protected the adverse effects of $\mathrm{CCl}_{4}$ on the nonspecific host response in the peritoneal macrophages of the mice (Sengupta et al., 2011).

Interestingly, there are several studies on the ability of $C$. longa to modulate the immune response of fish, chick, and prawn. $C$. longa increased plant defense by enhancing the defense-related genes such as defensin and chitinase of treated sunflower seedlings (Alsahli et al., 2018). The enhancement of host defense in fish has also been reported. C. longa leaf-enriched diet was fed to the fish to satiation twice daily for 12 weeks. Then, the fish was challenged with Aeromonas hydrophila. The highest stimulation on immunoglobulin M (IgM) level and lysozyme 
activity was observed in fish fed with $2.5 \%$ C. longa-fortified diets (Adeshina et al., 2017). A study reported that Mesocyclops thermocyclopoides enriched with $C$. longa enhanced the differential leukocyte number in fish (Cyprinus carpio), including enhancement of neutrophils, lymphocytes, monocytes, eosinophils, and basophils (Arunkumar et al., 2016). This result was supported by a previous study which reported the ability of $0.3 \%$ turmeric powder-enriched fish diet to enhance the white blood cell number significantly as compared to those of the control group (Mooraki et al., 2019). Turmeric in combination with rosemary (Rosmarinus officinalis) and thyme (Thymus vulgaris) increased the leukocrit levels in fish (Hassan et al., 2018).

C. longa was also able to enhance the immune response of prawns (Macrobrachium rosenbergii) after being infected by Vibrio alginolyticus. Identification using RT-PCR revealed that C. longa-enhanced feeds increased the gene expression of crustin and lysozyme in $M$. rosenbergii, indicating a remarkable increase in the expression of AMPs (antimicrobial peptides). Production of AMPs is a first-line host defense mechanism of innate immunity, and they are thought to be essential for organisms lacking adaptive immunity (Alambra et al., 2012). The ability of C. longa to modulate the immune response in chicks was also reported. C. longa powder constituted 2.5 and $7.5 \mathrm{~g} / \mathrm{kg}$ of the diet, which significantly enhanced lymphocyte percentage in chicks. Supplementation of the diet with the powder at $2.5 \mathrm{~g} / \mathrm{kg}$ of the diet resulted in a significant increase in anti-infectious bronchitis virus (IBV) titer compared to the control group (Naderi et al., 2014). In another study, $2.5 \%$ of C. longa-enriched diet protected chicken from Salmonella pullorum infection (Purwanti et al., 2018). Moreover, the cellular immunity of broiler chicken to phytohemagglutinin-P (PHA-P) was significantly higher in groups fed with higher amount of $C$. longa. The primary antibody titer to sRBCs was also stimulated (Sethy et al., 2017). These studies revealed that C. longa mostly enhanced the cellular and humoral responses of fish, chick, and prawns. Thus, this plant can be used as animal feed to enhance the immune defense of the animals.

Extensive cellular and animal studies have been performed to evaluate the immunomodulatory effects of $C$. longa by using various immune cells such as macrophages, monocytes, neutrophils, lymphocytes ( $\mathrm{T}$ and $\mathrm{B}$ cells), and NK cells. There is a need to explore the immune effect of the plant with other immune cells, particularly the antigen-presenting cells such as dendritic cells. The existing reports should be supported by exploring the effects of the plant samples on various animal disease models of immune-related and chronic inflammatory disorders. All the extracts of Curcuma species used in the in vitro and in vivo immunomodulating studies were not analyzed for their chemical constituents or standardized to marker compounds. C. longa samples were mostly in the form of crude aqueous and alcoholic extracts. Some of the samples were curcuminoids or polysaccharide-rich extracts, but the chemical composition of the extracts were not determined. It has been suggested that the curcuminoids and polysaccharides might be the main contributors for immunomodulatory activity of the plant. The extracts used should be determined qualitatively and quantitatively by using validated analytical methods such as reversed-phase HPLC methods. Some of the bioactive compounds-especially the curcuminoids-have been isolated from the extracts, and their mechanistic effects in modulating the immune system have been determined.

\section{Curcuma zanthorrhiza Roxb.}

In Vitro Immunomodulating Effect of $C$. zanthorrhiza

C. zanthorrhiza methanol extract has been reported to inhibit ROS generation in a luminol and lucigenin-enhanced chemiluminescence (CL) assay. C. zanthorrhiza rhizomes reduced ROS production from whole blood of human by in vitro study. Moreover, the extract significantly inhibited the release of ROS from zymosan-induced PMNs and macrophages. C. zanthorrhiza also showed strong inhibition on PMN migration, with an $\mathrm{IC}_{50}$ value of $2.5 \mu \mathrm{g} / \mathrm{ml}$ (Jantan et al., 2011). A previous study reported that the methanol extract of C. zanthorrhiza rhizomes showed strong inhibition on the expression of CD18/11a; meanwhile, the extract has low effect on leukocyte phagocytosis (Harun et al., 2015). The mRNA levels of IL- $1 \beta$, NF-kB p65, MMP-2, and MMP-8 on LPS-induced human gingival fibroblast-1 cells were reduced after treatment with crude polysaccharide extract of $C$. zanthorrhiza. The extract of C. zanthorrhiza inhibited MAPK/activator protein-1 (AP-1) signaling pathways. C. zanthorrhiza has been documented to exhibit anti-inflammatory activities in LPS-induced RAW264.7 monocytes and $\mathrm{H}_{2} \mathrm{O}_{2}$-treated $\mathrm{HT} 22$ hippocampal cells (Kim et al., 2018).

\section{In Vivo Immunomodulating Effect of C. zanthorrhiza}

Curcuminoid cider, a traditional fermented product made by the addition of Acetobacter xylinum to curcuminoid fraction isolated from C. zanthorrhiza, reduced the gene expression of IL1 $\beta$, TNFa, and chemokine in hypercholesterolemic rats (Hardiwati et al., 2019). The data were in accordance with a previous study which demonstrated the inhibitory activity of curcuminoid cider and curcuminoid fraction from C. zanthorrhiza on the gene expression of CD44, ICAM-1, iNOS, and LOX-1 in highcholesterol diet rats (Mauren et al., 2016). Volatile oil from $C$. zanthorrhiza enhanced the lymphocyte proliferation from human male B blood type (Miksusanti, 2012). C. zanthorrhiza extract administration was able to reduce inflammatory lymphocytes in alcohol-induced hepatitis in mice (Ilene et al., 2020). C. zanthorrhiza ethanol extracts strongly reduced cytokine gene expression, which include TNF- $\alpha$, IL- 6 , IL- $1 \beta$, and C-reactive protein (CRP) in the liver, adipose tissue, and muscle of high-fat diet-induced obese mice (Kim M-B et al., 2014). The crude polysaccharide extract of $C$. zanthorrhiza consisted of glucose, galactose, arabinose, xylose, mannose, and rhamnose, and was also reported to significantly enhance the phagocytosis of macrophages and the production of $\mathrm{NO}, \mathrm{H}_{2} \mathrm{O}_{2}, \mathrm{TNF}-\alpha$, and $\mathrm{PGE}_{2}$. In addition, it clearly enhanced phosphorylation of IкBa, suggesting a role as a NF- $\mathrm{kB}$ activator (Kim et al., 2007; Huang et al., 2010). C. zanthorrhiza-inhibited proinflammatory cytokine production in mice induced high-fat diet. $C$. zanthorrhiza extract at $100 \mathrm{mg} / \mathrm{kg}$ body weight/day decreased IL- $1 \beta$ gene expression by $89.9 \%$ compared to the control group (Ilene et al., 2020). C. zanthorrhiza was also reported to stimulate total and 
differential leukocytes in African catfish (Clarias gariepinus) (Lestari et al., 2019). C. zanthorrhiza rhizome in combination with Zingiber officinale rhizome, Vitex trifolia leaves, Echinacea purpurea, and citrus fruit in a herbal formula increased the number of macrophages phagocytizing Candida albicans as compared to those of $E$. purpurea-only group in mice. In addition, the herbal formula also displayed immunostimulatory activities on lymphocyte proliferation and the level of IgG actively phagocytizing $C$. albicans (Ikawati et al., 2019).

\section{Clinical Studies of C. zanthorrhiza on the Immune System}

An unsystematic clinical study of C. zanthorrhiza reported that $C$. zanthorrhiza extract reduced the population of B lymphocytes (Dewi et al., 2012). A previous study reported that $C$. zanthorrhiza in combination with C. mangga and Phyllanthus niruri maintained the levels of $\mathrm{CD}^{+}$in HIV/AIDS patients (Astana et al., 2018). C. zanthorrhiza in combination with Vitex trifolia did not cause liver and kidney damage after 14 days, 3 times a day treatment in women (Baroroh et al., 2011). Supplementation of C. zanthorrhiza with vitamin D3 was not able to decrease IL-6 level and elevate TGF- $\beta 1$ systemic lupus erythematosus (SLE) in patients with hypovitaminosis D (Wahono et al., 2017b). These data were supported by a double-blind randomized controlled study on active SLE patients with hypovitaminosis $\mathrm{D}$, which reported that addition of C. zanthorrhiza in vitamin D3 did not reduce IL-17 level as compared to those of singular vitamin D administration (Wahono et al., 2017a). Furthermore, a placebo-controlled double-blind clinical study showed that TNF- $\alpha$ release was reduced after treatment with the extract of $C$. zanthorrhiza for 4 weeks in SLE patients (Setiawati et al., 2017).

C. zanthorrhiza Roxb. is the second most popular plant among the genus Curcuma that has been investigated for its immunomodulating properties. Similar to C. longa, the crude extracts of C. zanthorrhiza were used in experimental studies to evaluate its in vivo immunomodulating effect using various animal models. There were a few in vitro studies, and the chemical constituents of the extracts were mostly not determined or the extracts were not standardized. Some clinical trials have been conducted on C. zanthorrhiza extracts, but they were unsystematic and not well designed. Despite the regulatory requirements for clinical studies and sufficient data not being generated on preclinical testing of C. zanthorrhiza, there were already reports on a few unsystematic case studies to evaluate the immunomodulating properties of C. zanthorrhiza in human. For clinical studies, sufficient preclinical testing should be generated using standardized extracts, which include bioavailability, and pharmacokinetic and toxicological studies, before they can be subjected to clinical studies.

\section{Curcuma aeruginosa Roxb.}

\section{In Vitro Immunomodulating of $C$. aeruginosa}

The methanol extract of C. aeruginosa at 100 and $6.25 \mu \mathrm{g} / \mathrm{ml}$ showed moderate inhibition on CD18/11a expression on the surface of phagocytes, which was determined using a flow cytometry method. The extract at the same concentrations also demonstrated low inhibition on phagocytosis of leukocytes (Harun et al., 2015). Investigation on the effect of $C$. aeruginosa methanol extract on ROS generation from polymorphonuclear cells (PMNs) and peritoneal macrophages in human whole blood revealed that the extract possessed ROS inhibitory activity for luminol-stimulated chemiluminescence (CL). C. aeruginosa rhizomes inhibited oxidative burst of PMNs and macrophages, with $\mathrm{IC}_{50}$ values of 1.8 and $4.6 \mu \mathrm{g} /$ $\mathrm{ml}$, respectively. Interestingly, $C$. aeruginosa extract also possessed significant ROS inhibitory activity for lucigeninenhanced CL. However, C. aeruginosa revealed low inhibition on PMN chemotaxis toward the chemoattractant, N-formylmethionyl-leucyl-phenylalanine (fMLP), with percentage inhibition of 49.9\% (Jantan et al., 2011).

\section{In Vivo Immunomodulating of C. aeruginosa}

C. aeruginosa extract, obtained by steam distillation, has been reported to increase the percentage of $\mathrm{CD}^{+}$and $\mathrm{CD}^{+}$cells (Anggriani et al., 2019). A previous study reported that $C$. aeruginosa ethanol extract was able to increase IFN- $\gamma$, TNF- $\alpha$, IL-2, and IL-12 levels in 7,12-dimethylbenz [a]anthracene (DMBA)-induced Wistar rats. The highest stimulation on cytokines release was shown after treatment with the ethanol extract of C. aeruginosa at a dose of $80 \mathrm{mg} / 200 \mathrm{~g}$ body weight (Sulfianti et al., 2019). The aqueous extract of C. aeruginosa in combination with Piper retrofractum and Curcuma zanthorrhiza supplemented in a fish fed at the concentrations of $0.5,1$, and $1.5 \%$, respectively, enhanced nonspecific immunity of Epinephelus fuscoguttatus. The addition of $C$. aeruginosa extract induced significant difference in the total leukocyte count of Epinephelus fuscoguttatus after being infected by Vibrio alginolyticus and V. parahaemolyticus during 15 days of observation. C. aeruginosa treatment increased the total leukocyte count on day 4 and day 8. Moreover, C. aeruginosa at concentration of $1 \%$ showed the strongest stimulation on phagocytosis activity, which was determined on day 8 (Setyati et al., 2019).

The in vitro and in vivo immunomodulating studies on $C$. aeruginosa were carried out on their crude aqueous and ethanol extracts. The bioactive metabolites contributing to the modulating effects were not identified. It is important to chemically characterize the extract to determine the bioactive compounds contributing to the immunomodulatory properties and mechanistic investigation to conclude the plant potency and effects on the immune-related disorders.

\section{Curcuma zedoaria (Christm.) Roscoe} In Vitro Immunomodulating Effect of $C$. zedoaria

C. zedoaria (Christm.) Roscoe rhizome extract has been reported to inhibit NO production from LPS-stimulated RAW264.7 cells. It has also been found to reduce iNOS and COX-2 expressions (Lee et al., 2019). In another study, C. zedoaria prevented $\beta$-hexosaminidase release in $\mathrm{RBL}-2 \mathrm{H} 3$ cells and showed passive cutaneous anaphylaxis reaction in mice. $\beta$-Hexosaminidase is a marker of antigen-IgE-mediated degranulation (Lobo et al., 2009). Essential oil from C. zedoaria was reported to reduce TNF- $\alpha$ release from L. monocytogenes 
and S. aureus-stimulated RAW264.7 cells (Huang et al., 2019). Polysaccharide fraction of $C$. zedoaria rhizome was found to enhance phagocytosis activity and splenocyte proliferation. It also stimulated the primary and secondary titers as well as delayed-type hypersensitivity response (Faradilla and Iwo, 2014). This work was supported by a previous study which showed that polysaccharide fraction of $C$. zedoaria enhanced phagocytosis of FITC-labeled Gram-negative bacteria (E. coli) or Gram-positive bacteria ( $S$. aureus) by peritoneal macrophages. It also stimulated two microbicidal routes, oxygen-dependent and oxygen-independent mechanisms. Lysosomal activity increased after treatment with polysaccharide fraction as well as in vivo and in vitro respiratory burst. It was reported that PMA-induced respiratory burst of peritoneal macrophage was higher than those of RAW 264 cells identified using luminolchemiluminescence-based assay. The production of $\mathrm{H}_{2} \mathrm{O}_{2}$, NO, and TNF- $\alpha$ was also enhanced at the doses of 10, 50, and $100 \mu \mathrm{g} / \mathrm{ml}$, dose dependently (Kim et al., 2001).

\section{In Vivo Immunomodulating Effect of $C$. zedoaria}

The effect of C. zedoaria extract on tumor progression and peripheral blood cells in $\mathrm{C} 57 \mathrm{Bl} / 6 \mathrm{~J}$ mice injected with $\mathrm{B} 16 \mathrm{~F} 10$ murine melanoma cells was determined using different routes of administration. A decrease in peritoneal cell number and a significant increase in total red and white blood cell counts were observed. Oral administration of the extract revealed a noteworthy increase only in the total leukocyte count (Carvalho et al., 2010). C. zedoaria has also been reported to stimulate immune response in fish. Supplemented diets with $C$. zedoaria increased the phagocytic rate and lysosome activity in Epinephelus coioedes fish. C. zedoaria was able to increase reactive oxygen production, identified using two different methods, NBT test and chemiluminescent assay (Nan et al., 2014).

Similar to the other Curcuma species already discussed, the metabolite profiles of C. zedoaria extracts were not determined. It is necessary to analyze the chemical constituents of the extracts or use standardized extracts in the studies as the phytochemical constituents of the plant may vary with variation in genetic adaptation of the plant population growing at different altitudes, its geographical distribution due to the changes in soil composition, and other environmental factors. Thus, using standardized extracts will ensure the dynamic change of varying amounts of phytochemical constituents in the plant is taken into consideration.

\section{Curcuma mangga Valeton \& Zijp}

\section{In Vitro Immunomodulating Effect of $C$. mangga}

A previous study reported in vitro NO inhibition activity of $C$. mangga which might contribute to its anti-inflammatory effect (Abas et al., 2006; Kaewkroek et al., 2009; Liu and Nair, 2011). Furthermore, C. mangga rhizome extract and its chloroform, hexane, and ethyl acetate fractions reduced NO production from LPS-induced RAW 264.7 cells. Among the fractions, the chloroform fraction showed the highest NO inhibition, followed by hexane, and then ethyl acetate fractions (Kaewkroek et al., 2009). A previous study of the methanol extract of C. mangga rhizomes on whole blood showed that the extract exhibited strong inhibitory activity upon activation by zymosan. C. mangga rhizome extract possessed high ROS inhibitory activity in PMNs and peritoneal macrophages as investigated in a luminol-enhanced CL assay. The extract also inhibited the release of ROS from PMNs and macrophages in a lucigenin-enhanced $\mathrm{CL}$ assay, with $\mathrm{IC}_{50}$ values of 0.9 and $6.6 \mu \mathrm{g} /$ $\mathrm{ml}$, respectively (Jantan et al., 2011). C. mangga methanol extract has also been found to significantly suppress the cell surface expression of CD18/11a as compared to the negative control. However, the extract of $C$. mangga rhizome at the concentration of 100 and $6.25 \mu \mathrm{g} / \mathrm{ml}$ showed immunostimulatory activity on phagocytosis of leukocytes (Harun et al., 2015).

\section{In Vivo Immunomodulating Effect of C. mangga}

C. mangga Valeton \& Zijp rhizome ethanol extract, its different organic fractions (hexane, chloroform, and ethyl acetate), and aqueous fraction have showed appreciable anti-inflammatory and analgesic activities in mice and inflammatory models using croton oilinduced mouse ear edema and carrageenan-induced rat paw edema. The plant extract and its fractions at $200 \mathrm{mg} / \mathrm{kg}$ demonstrated analgesic activity by reducing the number of writhing and also produced antinociception using hot plate and formalin test. At $200 \mathrm{mg} / \mathrm{kg}$, the hexane and chloroform fractions significantly prolonged the latency time, but ethyl acetate and aqueous fractions were not active. In addition, the ethanol extract of $C$. mangga rhizome and its fractions displayed significant reduction of paw and ear edema in rat (Ruangsang et al., 2010). Our previous study reported that the n-hexane, ethyl acetate, and ethanol extracts of $C$. mangga rhizomes at the doses of 100,200, and $400 \mathrm{mg} / \mathrm{kg}$ increased the carbon clearance rate, indicating the enhancement of carbon engulfment by cells in the reticuloendothelial system of mice, thus stimulating the phagocytosis activity in mice (Yuandani and Suwarso, 2017a; Yuandani et al., 2019). In addition, the $C$. mangga rhizome ethanol extract exhibited stimulation of antibody titer against bovine red blood cells in a dose-dependent way by using the hemagglutination method. The cellular immunity was also enhanced after treatment with $C$. mangga ethanol extract by increasing the bovine red blood cell-induced mice paw volume (Yuandani et al., 2018). Moreover, the ethanol extract of C. mangga rhizome stimulated the immune response in doxorubicininduced immunosuppressive rats, which was indicated by the elevation of antibody titer and delayed hypersensitivity (DTH) response (Yuandani et al., 2020).

As with other Curcuma species already discussed, the effects of C. mangga on the immune cells and experimental animals may vary considerably, depending on the experimental conditions used, including the solvent of extraction, extraction method, cell line, animal model, treatment scheme, and different disease animal models. Dosage and concentration of raw extracts of the plant are crucial in order to achieve the desired benefit. Thus, to ensure the results are reproducible when the study is replicated, the same methodology has to be used by other researchers.

\section{Curcuma amada Roxb.}

The ethanol, petroleum ether, chloroform, and acetone extracts of C. amada enhanced the phagocytosis activity of PMNs. The ethanol extract at a concentration $3 \mathrm{mg} / \mathrm{ml}$ showed the highest 
TABLE 2 | Bioactive compounds of Curcuma species with immunomodulating activity and their mechanisms of action.

\begin{tabular}{|c|c|c|c|c|c|c|c|}
\hline Main compound & Species & Subjects & $\begin{array}{l}\text { Study } \\
\text { design }\end{array}$ & $\begin{array}{l}\text { Immunomodulatory } \\
\text { activities }\end{array}$ & Modulation & $\begin{array}{l}\text { Parameters/ } \\
\text { mediators } \\
\text { affected }\end{array}$ & References \\
\hline \multirow[t]{31}{*}{ Curcumin } & $\begin{array}{l}\text { Curcuma } \\
\text { species }\end{array}$ & $\begin{array}{l}\text { High glucose- } \\
\text { cultured monocytes }\end{array}$ & in vitro & Cytokine production & $\downarrow$ & $\begin{array}{l}\text { IL6, IL8, TNF } \alpha \text {, } \\
\text { and MCP1 }\end{array}$ & Jain et al. (2009) \\
\hline & & $\begin{array}{l}\text { Streptozotocin- } \\
\text { induced rats }\end{array}$ & in vivo & Cytokine production & $\downarrow$ & $\begin{array}{l}\text { IL6, TNF } \alpha \text {, and } \\
\text { MCP1 }\end{array}$ & Jain et al. (2009) \\
\hline & & Mice pancreatic & in vivo & Leukocyte infiltration & $\downarrow$ & Leukocytes & Castro et al. (2014) \\
\hline & & $\begin{array}{l}\text { M-stimulated } \\
\text { BDC2.5-splenocytes }\end{array}$ & in vitro & T-cell proliferation & $\downarrow$ & $\begin{array}{l}\mathrm{CD}^{+}, \mathrm{T} \text { cells, } \\
\text { and IFN- } \gamma\end{array}$ & Castro et al. (2014) \\
\hline & & $\begin{array}{l}\text { BDC2.5 mice } \mathrm{T} \\
\text { lymphocite }\end{array}$ & in vitro & T-cell proliferation & $\downarrow$ & T lymphocyte & Castro et al. (2014) \\
\hline & & PMN leukocytes & in vitro & DHA synthesis & $\uparrow$ & $\mathrm{DHA}$ & $\begin{array}{l}\text { Pisani et al. (2009), } \\
\text { Wu et al. (2015) }\end{array}$ \\
\hline & & PMN leukocytes & in vitro & ROS production & $\downarrow$ & ROS & $\begin{array}{l}\text { Pisani et al. (2009), } \\
\text { Wu et al. (2015) }\end{array}$ \\
\hline & & $\begin{array}{l}\text { LPS-induced mice } \\
\text { mastitis }\end{array}$ & in vivo & $\begin{array}{l}\text { Myeloperoxidase } \\
\text { activity }\end{array}$ & $\downarrow$ & MPO & Fu et al. (2014) \\
\hline & & $\begin{array}{l}\text { LPS-induced mice } \\
\text { mastitis }\end{array}$ & in vivo & Cytokine production & $\downarrow$ & $\begin{array}{l}\text { TNF- } \alpha, \text { IL-6, IL- } \\
1 \beta \text {, and TLR4 }\end{array}$ & Fu et al. (2014) \\
\hline & & $\begin{array}{l}\text { LPS-induced mice } \\
\text { mastitis }\end{array}$ & in vivo & Phosphorylation & $\downarrow$ & $\begin{array}{l}\text { I B }-\alpha \text { and NF- } \\
\kappa B \text { p65 }\end{array}$ & Fu et al. (2014) \\
\hline & & Microglial cells & in vitro & NO production & $\downarrow$ & NO & $\begin{array}{l}\text { Cianciulli et al. } \\
\text { (2016) }\end{array}$ \\
\hline & & Microglial cells & in vitro & Phosphorylation & $\downarrow$ & $\begin{array}{l}\mathrm{IL}-1 \beta, \mathrm{IL}-6, \mathrm{TNF}- \\
\alpha, \text { and PI3K/Akt }\end{array}$ & $\begin{array}{l}\text { Cianciulli et al. } \\
\text { (2016) }\end{array}$ \\
\hline & & Microglial cells & in vitro & $\begin{array}{l}\mathrm{NF}-\kappa \mathrm{B} \text { and iNOS } \\
\text { expression }\end{array}$ & $\downarrow$ & $N F-\kappa B$ and iNOS & $\begin{array}{l}\text { Cianciulli et al. } \\
\text { (2016) }\end{array}$ \\
\hline & & Microglial cells & in vitro & Cytokine production & $\downarrow$ & $\begin{array}{l}\mathrm{NO}, \mathrm{PGE}_{2}, \mathrm{TNF}- \\
\alpha, \text { iNOS, and } \\
\text { COX-2 }\end{array}$ & Yu et al. (2018) \\
\hline & C. longa & Healthy albino mice & in vivo & $\begin{array}{l}\text { White blood cells } \\
\text { production and weight } \\
\text { lymphoid }\end{array}$ & $\uparrow$ & $\begin{array}{l}\text { Lymphoid organs } \\
\text { and white blood } \\
\text { cells }\end{array}$ & $\begin{array}{l}\text { Afolayan et al. } \\
\text { (2018) }\end{array}$ \\
\hline & & Dendritic cells & in vitro & $\begin{array}{l}\text { Surface molecule } \\
\text { expression }\end{array}$ & $\downarrow$ & $\begin{array}{l}\text { CD80, CD86, } \\
\text { MHC class II, and } \\
\text { IL-1 }\end{array}$ & Kim et al. (2005) \\
\hline & & Dendritic cells & in vitro & Cytokine production & $\downarrow$ & $\begin{array}{l}\text { IL-6, IL-12, and } \\
\text { TNF- } \alpha\end{array}$ & Kim et al. (2005) \\
\hline & & Dendritic cells & in vitro & $\begin{array}{l}\text { NF-кB p65 } \\
\text { translocation }\end{array}$ & $\downarrow$ & NF-кB p65 & Kim et al., 2005 \\
\hline & & $\begin{array}{l}\text { Bronchoalveolar of } \\
\text { Balb/c mice }\end{array}$ & in vivo & Allergic response & $\downarrow$ & Eosinophils & $\begin{array}{l}\text { Ravikumar and } \\
\text { Kavitha (2020) }\end{array}$ \\
\hline & & $\begin{array}{l}\text { Bronchoalveolar of } \\
\text { Balb/c mice }\end{array}$ & in vivo & Cytokine production & $\downarrow$ & IL-4 & $\begin{array}{l}\text { Ravikumar and } \\
\text { Kavitha (2020) }\end{array}$ \\
\hline & & PBMCs & in vitro & T-cell proliferation & $\downarrow$ & Lymphocyte & Yadav et al. (2005) \\
\hline & & PBMCs & in vitro & Cytokine production & $\downarrow$ & IL-2 and TNF- $\alpha$ & Yadav et al. (2005) \\
\hline & & PBMCs & in vitro & $N F-\kappa B$ & $\downarrow$ & $N F-\kappa B$ & Yadav et al. (2005) \\
\hline & & $\begin{array}{l}\text { Erythroleukemic cell } \\
\text { line K562 }\end{array}$ & in vitro & Cytotoxicity & $\uparrow$ & NK cell & Yadav et al. (2005) \\
\hline & & Lupus BALB/c mice & in vivo & $\begin{array}{l}\text { Adaptive immune } \\
\text { response }\end{array}$ & $\downarrow$ & $\begin{array}{l}\text { Th1, Th2, and } \\
\text { Th17 }\end{array}$ & Kalim et al. (2017) \\
\hline & & Lupus BALB/c mice & in vivo & ANA levels & $\downarrow$ & ANA & Kalim et al. (2017) \\
\hline & & $\begin{array}{l}\text { Monocytes and liver } \\
\text { macrophages }\end{array}$ & in vivo & ROS production & $\downarrow$ & ROS & $\begin{array}{l}\text { Inzaugarat et al. } \\
(2017)\end{array}$ \\
\hline & & Monocytes & in vivo & $\begin{array}{l}\text { TNF- } \alpha \text { and IFN- } \gamma \\
\text { production }\end{array}$ & $\uparrow$ & TNF- $\alpha$ and IFN- $\gamma$ & $\begin{array}{l}\text { Inzaugarat et al. } \\
(2017)\end{array}$ \\
\hline & C. longa & Fish & in vivo & Immune response & $\uparrow$ & Immune & $\begin{array}{l}\text { Alambra et al. } \\
\text { (2012) }\end{array}$ \\
\hline & C. zedoaria & RBL-2H3 cells & in vitro & $\begin{array}{l}\text { beta-Hexosaminidase } \\
\text { production }\end{array}$ & $\downarrow$ & $\begin{array}{l}\text { Beta- } \\
\text { hexosaminidase }\end{array}$ & $\begin{array}{l}\text { Matsuda et al. } \\
(2004)\end{array}$ \\
\hline & & RBL-2H3 cells & in vitro & Cytokine production & $\uparrow$ & TNF- $\alpha$ and IL-4 & $\begin{array}{l}\text { Matsuda et al. } \\
(2004)\end{array}$ \\
\hline Turmeronol & C. longa & RAW264.7 cells & in vitro & $\begin{array}{l}\mathrm{PGE}_{2} \text { and } \mathrm{NO} \\
\text { production }\end{array}$ & $\downarrow$ & $\mathrm{PGE}_{2}$ and $\mathrm{NO}$ & $\begin{array}{l}\text { Okuda-Hanafusa } \\
\text { et al. (2019) }\end{array}$ \\
\hline
\end{tabular}

(Continued on following page) 
TABLE 2 | (Continued) Bioactive compounds of Curcuma species with immunomodulating activity and their mechanisms of action.

\begin{tabular}{|c|c|c|c|c|c|c|c|}
\hline Main compound & Species & Subjects & $\begin{array}{l}\text { Study } \\
\text { design }\end{array}$ & $\begin{array}{l}\text { Immunomodulatory } \\
\text { activities }\end{array}$ & Modulation & $\begin{array}{l}\text { Parameters/ } \\
\text { mediators } \\
\text { affected }\end{array}$ & References \\
\hline & & RAW264.7 cells & in vitro & Cytokine production & $\downarrow$ & $\mathrm{IL}-1 \beta$ and IL-6 & $\begin{array}{l}\text { Okuda-Hanafusa } \\
\text { et al. (2019) }\end{array}$ \\
\hline & & $\begin{array}{l}\text { Cytoplasm into the } \\
\text { nucleus }\end{array}$ & in vitro & $\mathrm{NF}-\kappa \mathrm{B}$ translocation & $\downarrow$ & $N F-\kappa B$ & $\begin{array}{l}\text { Okuda-Hanafusa } \\
\text { et al. (2019) }\end{array}$ \\
\hline Curdione & $\begin{array}{l}\text { C. } \\
\text { aeruginosa }\end{array}$ & CD95 protein & in silico & Docking score & $\downarrow$ & $\begin{array}{l}\text { Curdione to } \\
\text { CD95 }\end{array}$ & $\begin{array}{l}\text { Anggriani et al. } \\
\text { (2019) }\end{array}$ \\
\hline 1,8-cineol & & CD95 protein & in silico & Docking score & $\uparrow$ & $\begin{array}{l}\text { 1,8-cineol to } \\
\text { CD95 }\end{array}$ & $\begin{array}{l}\text { Anggriani et al. } \\
\text { (2019) }\end{array}$ \\
\hline Isocurcumenol & & $\begin{array}{l}\text { Chicken embryo } \\
\text { fibroblast }\end{array}$ & in vitro & Toxicity & - & $\begin{array}{l}\text { Fibroblast cells } \\
\text { and lymphocytes }\end{array}$ & $\begin{array}{l}\text { Lakshmi et al. } \\
\text { (2011) }\end{array}$ \\
\hline Isoprocurcumenol & & RAW264.7 cells & in vitro & NO activity & $\downarrow$ & NO & Lee et al. (2019) \\
\hline Germacrone & C. zedoaria & RAW264.7 cells & in vitro & NO activity & $\downarrow$ & $\mathrm{NO}$ & Lee et al. (2019) \\
\hline Curzerenone & & RAW264.7 cells & in vitro & NO activity & $\downarrow$ & $\mathrm{NO}$ & Lee et al., 2019 \\
\hline Curcumenol & & RAW264.7 cells & in vitro & NO activity & $\downarrow$ & $\mathrm{NO}$ & Lee et al. (2019) \\
\hline \multirow[t]{2}{*}{ Curcuzedoalide } & & RAW264.7 cells & in vitro & NO activity & $\downarrow$ & $\mathrm{NO}$ & Lee et al. (2019) \\
\hline & & RAW264.7 cells & in vitro & $\begin{array}{l}\text { iNOS and COX-2 } \\
\text { response }\end{array}$ & $\downarrow$ & iNOS and COX-2 & Lee et al. (2019) \\
\hline \multirow[t]{2}{*}{ Dihydrocurcumin } & & RBL-2H3 cells & in vitro & $\begin{array}{l}\text { beta-Hexosaminidase } \\
\text { production }\end{array}$ & $\downarrow$ & $\begin{array}{l}\text { beta- } \\
\text { Hexosaminidase }\end{array}$ & \\
\hline & & RBL-2H3 cells & in vitro & Cytokine production & $\uparrow$ & TNF- $\alpha$ and IL-4 & $\begin{array}{l}\text { Matsuda et al. } \\
\text { (2004) }\end{array}$ \\
\hline \multirow[t]{2}{*}{ Tetrahydrodemethoxycurcumin } & & RBL-2H3 cells & in vitro & $\begin{array}{l}\text { beta-Hexosaminidase } \\
\text { production }\end{array}$ & $\downarrow$ & $\begin{array}{l}\text { beta- } \\
\text { Hexosaminidase }\end{array}$ & $\begin{array}{l}\text { Matsuda et al. } \\
\text { (2004) }\end{array}$ \\
\hline & & RBL-2H3 cells & in vitro & Cytokine production & $\uparrow$ & TNF- $\alpha$ and IL-4 & $\begin{array}{l}\text { Matsuda et al. } \\
\text { (2004) }\end{array}$ \\
\hline \multirow[t]{2}{*}{ Tetrahydrobisdemethoxycurcumin } & & RBL-2H3 cells & in vitro & $\begin{array}{l}\text { Hexosaminidase } \\
\text { production }\end{array}$ & $\downarrow$ & $\begin{array}{l}\text { beta- } \\
\text { Hexosaminidase }\end{array}$ & $\begin{array}{l}\text { Matsuda et al. } \\
\text { (2004) }\end{array}$ \\
\hline & & RBL-2H3 cells & in vitro & Cytokine production & $\uparrow$ & TNF- $\alpha$ and IL-4 & $\begin{array}{l}\text { Matsuda et al. } \\
\text { (2004) }\end{array}$ \\
\hline \multirow[t]{2}{*}{$\begin{array}{l}\text { 1,7-bis(4-hydroxyphenyl)-1,4,6- } \\
\text { heptatrien-3-one }\end{array}$} & & $\begin{array}{l}\text { Lipopolysaccharide } \\
\text { (LPS)-activated } \\
\text { macrophages }\end{array}$ & in vitro & TNF- $\alpha$ production & $\downarrow$ & TNF- $\alpha$ & Jang et al. (2001) \\
\hline & & Macrophages & in vitro & $\begin{array}{l}\text { NO production and } \\
\text { iNOS expression }\end{array}$ & $\downarrow$ & $\mathrm{NO}$ and iNOS & Jang et al. (2004) \\
\hline Procurcumenol & & $\begin{array}{l}\text { lipopolysaccharide } \\
\text { (LPS)-activated } \\
\text { macrophages }\end{array}$ & in vitro & TNF- $\alpha$ production & $\downarrow$ & $\mathrm{TNF}-\alpha$ & Jang et al. (2001) \\
\hline \multirow[t]{2}{*}{ Xanthorrhizol } & $\begin{array}{l}\text { C. } \\
\text { zanthorrhiza }\end{array}$ & $\begin{array}{l}\text { Human gingival } \\
\text { fibroblast- } 1 \text { cells }\end{array}$ & in vitro & mRNA levels & $\downarrow$ & $\begin{array}{l}\text { IL-1 } \beta, N F-\kappa B \\
\text { p65, MMP-2, } \\
\text { and MMP-8 }\end{array}$ & Kim et al. (2018) \\
\hline & & RAW 264.7 cell line & in vitro & $\begin{array}{l}\text { MAPK and AP-1 } \\
\text { response }\end{array}$ & $\downarrow$ & MAPK and AP-1 & Kim et al. (2018) \\
\hline \multirow[t]{3}{*}{ Demethoxycurcumin } & C. mangga & RAW 264.7 cell line & in vitro & NO production & $\downarrow$ & NO & $\begin{array}{l}\text { Kaewkroek et al. } \\
\text { (2009) }\end{array}$ \\
\hline & & RAW 264.7 cell line & in vitro & $\begin{array}{l}\mathrm{NO} \text { and } \mathrm{PGE}_{2} \\
\text { production }\end{array}$ & $\downarrow$ & $\mathrm{NO}$ and $\mathrm{PGE}_{2}$ & $\begin{array}{l}\text { Kaewkroek et al. } \\
\text { (2010) }\end{array}$ \\
\hline & & RAW 264.7 cell line & in vitro & mRNA expressions & $\downarrow$ & iNOS and COX-2 & $\begin{array}{l}\text { Kaewkroek et al. } \\
(2010)\end{array}$ \\
\hline \multirow[t]{3}{*}{ Bisdemethoxycurcumin } & & RAW 264.7 cell line & in vitro & NO production & $\downarrow$ & $\mathrm{NO}$ & $\begin{array}{l}\text { Kaewkroek et al. } \\
(2009)\end{array}$ \\
\hline & & RAW 264.7 cell line & in vitro & $\begin{array}{l}\mathrm{NO} \text { and } \mathrm{PGE}_{2} \\
\text { production }\end{array}$ & $\downarrow$ & $\mathrm{NO}$ and $\mathrm{PGE}_{2}$ & $\begin{array}{l}\text { Kaewkroek et al. } \\
\text { (2010) }\end{array}$ \\
\hline & & RAW 264.7 cell line & in vitro & mRNA expressions & $\downarrow$ & iNOS and COX-2 & $\begin{array}{l}\text { Kaewkroek et al. } \\
\text { (2010) }\end{array}$ \\
\hline \multirow{2}{*}{$\begin{array}{l}\text { 4-[(1R, 4aR, 8aR)-decahydro-5, 5, } \\
\text { 8a-trimethyl-2-methylene-1- } \\
\text { naphthalenyl]-, (3E)-rel }\end{array}$} & & RAW 264.7 cell line & in vitro & $\begin{array}{l}\mathrm{NO} \text { and } \mathrm{PGE}_{2} \\
\text { production }\end{array}$ & $\downarrow$ & $\mathrm{NO}$ and $\mathrm{PGE}_{2}$ & $\begin{array}{l}\text { Kaewkroek et al. } \\
\text { (2009) }\end{array}$ \\
\hline & & RAW 264.7 cell line & in vitro & mRNA expressions & $\downarrow$ & iNOS and COX-2 & $\begin{array}{l}\text { Kaewkroek et al. } \\
(2009)\end{array}$ \\
\hline $\begin{array}{l}\text { 15,16 bisnorlabda-8(17), 11-dien- } \\
\text { 13-one }\end{array}$ & & RAW 264.7 cell line & in vitro & $\begin{array}{l}\mathrm{NO} \text { and } \mathrm{PGE}_{2} \\
\text { production }\end{array}$ & $\downarrow$ & $\mathrm{NO}$ and $\mathrm{PGE}_{2}$ & $\begin{array}{l}\text { Kaewkroek et al. } \\
\text { (2010) }\end{array}$ \\
\hline
\end{tabular}


TABLE 2 | (Continued) Bioactive compounds of Curcuma species with immunomodulating activity and their mechanisms of action.

\begin{tabular}{|c|c|c|c|c|c|c|c|}
\hline Main compound & Species & Subjects & $\begin{array}{c}\text { Study } \\
\text { design }\end{array}$ & $\begin{array}{l}\text { Immunomodulatory } \\
\text { activities }\end{array}$ & Modulation & $\begin{array}{c}\text { Parameters/ } \\
\text { mediators } \\
\text { affected }\end{array}$ & References \\
\hline & & RAW 264.7 cell line & in vitro & mRNA expressions & $\downarrow$ & iNOS and COX-2 & $\begin{array}{l}\text { Kaewkroek et al. } \\
\text { (2010) }\end{array}$ \\
\hline \multirow[t]{2}{*}{$\begin{array}{l}\text { (E)-15,15-diethoxylabda-8 (17),12- } \\
\text { dien-16-al }\end{array}$} & & RAW 264.7 cell line & in vitro & $\begin{array}{l}\mathrm{NO} \text { and } \mathrm{PGE}_{2} \\
\text { production }\end{array}$ & $\downarrow$ & $\mathrm{NO}$ and $\mathrm{PGE}_{2}$ & $\begin{array}{l}\text { Kaewkroek et al. } \\
(2010)\end{array}$ \\
\hline & & RAW 264.7 cell line & in vitro & mRNA expressions & $\downarrow$ & iNOS and COX-2 & $\begin{array}{l}\text { Kaewkroek et al. } \\
(2010)\end{array}$ \\
\hline
\end{tabular}

stimulation on percentage of phagocytosis. Further study on delayed hypersensitivity response against sRBCs showed that the ethanol extract of $C$. amada increased the paw volume. Moreover, the ethanol extract at the doses of 100, 200, and $400 \mathrm{mg} / \mathrm{kg}$ enhanced the antibody titer dose-dependently (Karchuli and Pradhan, 2011). Supercritical carbon dioxide $\left(\mathrm{CO}_{2}\right)$ extract prepared from C. amada rhizomes has potential to be used for the treatment of immune disorder such as autoimmune diseases. Specifically, the extract can be used to treat or prevent hypersensitivity diseases, in particular IgEmediated allergic reactions as well as autoimmune disorders (Weidner et al., 2001). C. amada in combination with Tinospora cordifolia, Piper longum, and Albizia lebbeck in a herbal preparation can be used to treat allergy (Palpu et al., 2008). The chemical constituents responsible for eliciting the activity were not determined, although a few potent activities have been reported on C. amada extract. There is a need to proceed to study in detail the underlying mechanisms on relevant signaling events followed by in vivo studies to explore the potential of this plant as a natural immunomodulating agent.

\section{Immunomodulatory Effects of Bioactive Compounds of Curcuma Species}

Plants in the genus Curcuma contain many compounds which contribute to the immunomodulatory activity of the plants, as shown in Table 2. Among the compounds from Curcuma species, curcumin and xanthorrhizol have been discussed in detail in this review as they have been widely investigated for their immunomodulating effects on the innate and adaptive immune system. Other compounds including turmeronols, curdione, curcuzedoalide, demethoxycurcumin, bisdemethoxycurcumin, dihydrocurcumin, curcumenol, epi-procurcumenol, isocurcumenol, and iso-procurcumenol germacrone are also included in this review, but their data are limited as they have not been well investigated for their immunomodulating effects. The chemical structures of these compounds are included in Figure 2.

\section{Curcumin}

It is a major compound of $C$. longa and can also be found in other Curcuma species. This natural diarylheptanoid compound has been mainly isolated from the rhizomes of C. longa and studied extensively for various pharmacological activities, including antioxidant, anti-inflammatory, immunomodulatory, antiangiogenic, anticancer, antiproliferative, and proapoptotic. It has been one of the most intensively investigated compounds for its immunomodulatory properties. Many preclinical investigations which include in vitro cell assays and in vivo studies in animal models have been carried out on curcumin to evaluate its modulatory effects in the immune system. It is also undergoing extensive clinical trials based on its antiinflammatory properties for the treatment of cancer.

\section{In Vitro Immunomodulating Effect of Curcumin}

The immunomodulating activity of curcumin has been demonstrated by many in vitro studies using several immune cells. Curcumin has been shown to inhibit inflammatory responses by suppressing COX-2 and NO, NF-кB, iNOS, and lipoxygenase in IFN- $\gamma$ or TNF- $\alpha$-activated macrophages and NK cells (Surh et al., 2001). A study by Jain et al. (2009) revealed that curcumin significantly reduced the production of IL-6, IL-8, TNF- $\alpha$, and MCP-1 from high glucose-cultured monocytes. Low concentration of curcumin reduced NOS activity and NO production from macrophages. In another study, curcumin inhibited the immunostimulatory function of dendritic cells, leading to the reduction of CD80, CD86, and MHC class II expression, but not MHC class I expression as well as IL-12 expression and cytokine release (IL-1, IL-6, and TNF- $\alpha$ ). Curcumin also inhibited LPS-induced MAPK activation and the translocation of NF-B p65 as well as impaired induction of Th1 responses (Kim et al., 2005). Gao et al. (2004) demonstrated that curcumin inhibited pro-inflammatory cytokine (TNF- $\alpha$, IL1, IL-12, and IL-6) expression in PMA or LPS-activated macrophages, dendritic cells, monocytes, and splenic lymphocytes. Curcumin has also been found to suppress PHAstimulated lymphocyte proliferation and IL-2 release as well as transcription factor NF-KB and TNF- $\alpha$ production from LPSstimulated PBMC to enhance NK cell cytotoxicity (Yadav et al., 2005). Curcumin has been shown to be able to increase $\omega-3$ polyunsaturated fatty acid (PUFA) synthesis in the brain. An in vitro study has showed that PUFAs have beneficial effects on stimulating immune response by stimulating neutrophil phagocytosis activity, while decreasing the release of ROS in goat neutrophils (Pisani et al., 2009; Wu et al., 2015). 
<smiles>COc1cc(/C=C/C(=O)CC(=O)/C=C/c2ccc(O)c(OC)c2)ccc1O</smiles>

curcumin<smiles>O=C(/C=C/c1ccc(O)cc1)CC(=O)/C=C/c1ccc(O)cc1</smiles>

bisdemethoxycurcumin
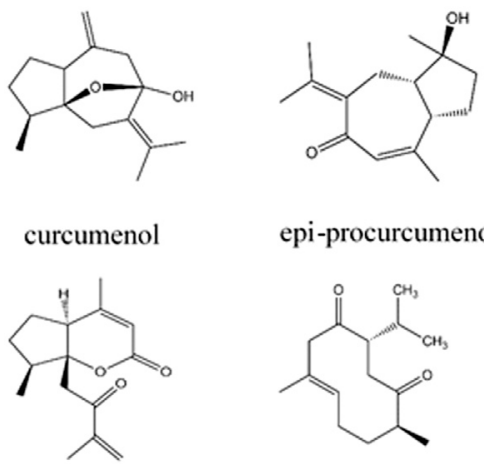

curcuzedoalide epi-procurcumenol

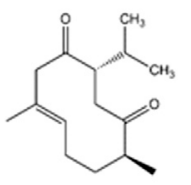

curdione<smiles>COc1cc(/C=C/C(=O)CC(=O)/C=C/c2ccc(O)cc2)ccc1O</smiles>

demethoxycurcumin

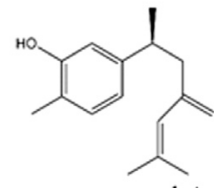

turmeronol A

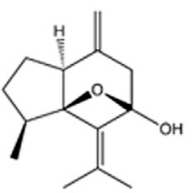

isocurcumenol<smiles>CC1=CCC(=C(C)C)C(=O)CC(C)=CC1</smiles>

germacrone

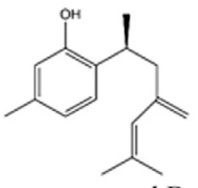

turmeronol B

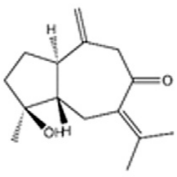

iso-procurcumenol<smiles>CC(C)=CCCC(C)c1ccc(C)c(O)c1</smiles>

xanthorrhizol

FIGURE 2 | Chemical structures of potential immunomodulators from Curcuma species.

Curcumin also increased ROS production from linoleic acid-stimulated monocytes and liver macrophages as well as TNF- $\alpha$ production from leptin-induced monocytes and IFN- $\gamma$ release from $\mathrm{CD}^{+}{ }^{+} \mathrm{T}$ cells (Inzaugarat et al., 2017). Pretreatment with curcumin significantly reduced the production of $\mathrm{NO}$, the expression and release of TNF- $\alpha$, IL-1 $\beta$, IL-6, PI3K/Akt phosphorylation, NF- $\kappa \mathrm{B}$ activation, and iNOS expression in LPS-stimulated microglial cells (Cianciulli et al., 2016). In addition, $\mathrm{NO}, \mathrm{PGE}_{2}$, and TNF- $\alpha$ production as well as iNOS and COX-2 expression in LTA-activated microglial cells were reduced by curcumin ( $\mathrm{Yu}$ et al., 2018). In an in silico study, curcumin has been shown to bind to viral S1 protein, which is important for SARS-CoV-2 entry; hence, it may prevent cytokine storm in a severe form of COVID-19 (Pawitan, 2020). The pathways and inflammatory mediators involved in the immunomodulating property of curcumin are illustrated in Figure 3.

\section{In Vivo Immunomodulating Effect of Curcumin}

In vivo studies to determine the immunomodulatory effects of curcumin were carried out using several animal models. Curcumin reduced the levels of IL6, TNFa, and MCP1 in streptozotocin-induced type 1 diabetes rats. Moreover, curcumin prevented pancreatic leukocytes infiltration that might initiate $\beta$-cell destruction. In addition, curcumin reduced $\mathrm{CD}^{+} \mathrm{T}$ cell proliferation and IFN- $\gamma$ release from M-stimulated BDC2.5-splenocytes as well as reduced LPS/IFN$\gamma$-induced dendritic cell maturation. Antigen-specific
T-lymphocyte proliferation has also been reduced by curcumin action on both $\mathrm{T}$ cells and antigen-presenting cells (APCs) (Castro et al., 2014). Administration of curcumin to lactating mice prevented mice mastitis by reducing the MPO activity; expression of TNF- $\alpha$, IL-6, IL-1 $\beta$, TLR4; and phosphorylation of I $\kappa \mathrm{B}-\alpha$ and NF- $\kappa \mathrm{B}$ p65 after being induced by LPS (Fu et al., 2014). Nanoparticulate curcumin demonstrated stronger activity on cellular and humoral immunity, and increased lymphoid organs and white blood cell production than those of control (Afolayan et al., 2018). A previous study reported that curcumin displayed immunomodulatory effects in comorbid diabetic asthma mice by reducing eosinophil number and Il-4 level with a high IFN- $\gamma$ to IL-4 ratio in the blood and bronchoalveolar after ovalbumin injection (Ravikumar and Kavitha, 2020). Administration of curcumin to pristaneinduced lupus mice decreased Th1, Th2, and Th17 and slightly increased Treg percentages. In addition, ANA levels were also decreased after curcumin treatment (Kalim et al., 2017). Curcumin was able to enhance immune response in Macrobrachium rosenbergii after being challenged with Vibrio alginolyticus (Alambra et al., 2012).

\section{Clinical Studies of Curcumin on Immune System}

Presently, curcumin is under extensive clinical investigation where there are 116 ongoing clinical trials on curcumin, the status of which can be found on http://www.clinicaltrials.gov/. Among the clinical trials on curcumin, 99 of them were based on its anti-inflammatory properties. Cancer (e.g., breast, pancreatic, 

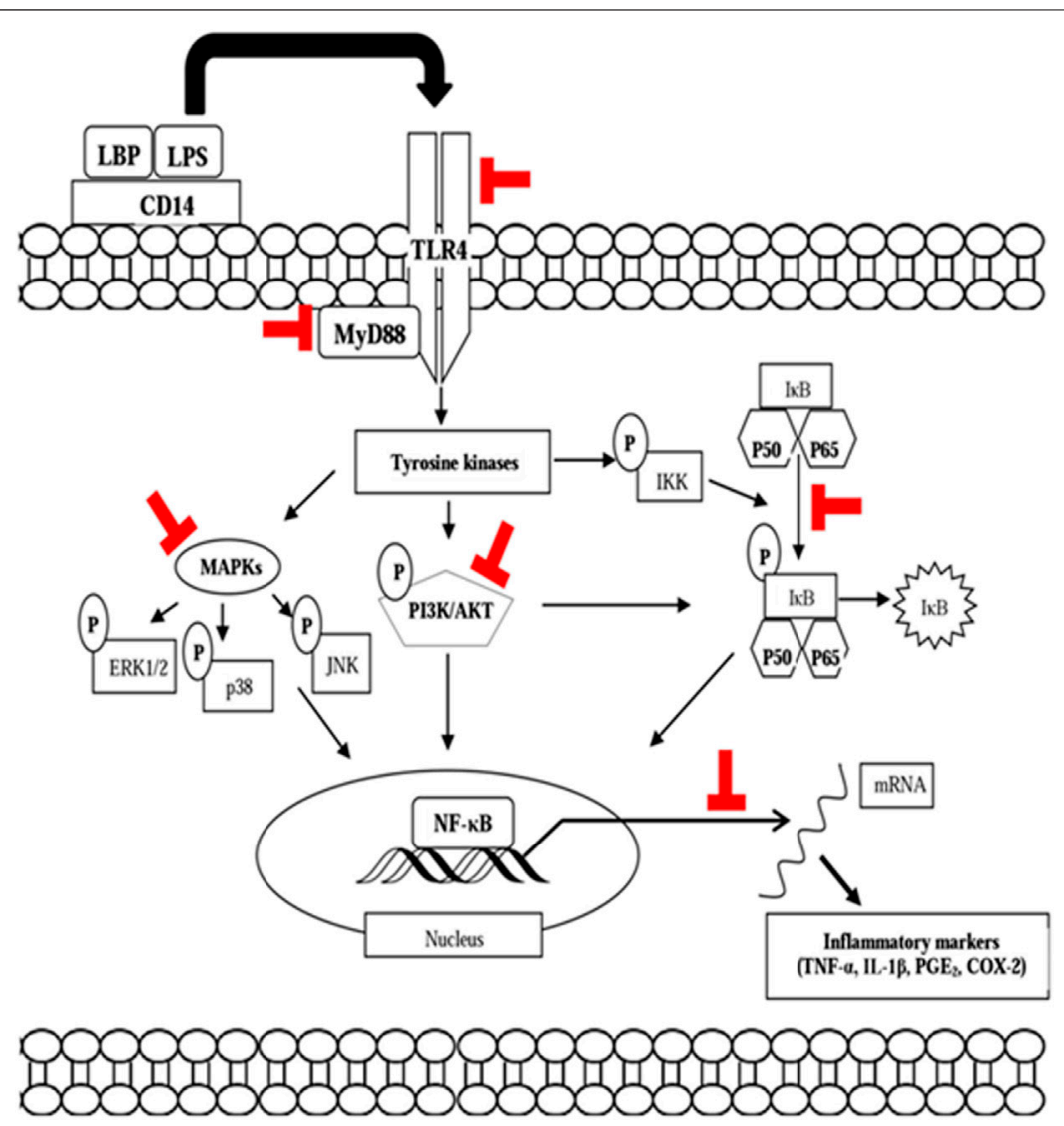

FIGURE 3 | Modulatory effects of curcumin on the NF-kB, MAPK, and Akt signaling pathways. The thick red block sign indicates the possible point of modulation of the signal transduction pathways. NF-kB, nuclear factor kappa $\beta$; MAPK, mitogen-activated protein kinase; PI3K/Akt, phosphatidylinositol 3-kinase and protein kinase B; P, phosphoryl group.

lung, colorectal, and prostate), inflammatory bowel diseases (IBD; Crohn's disease and ulcerative colitis) and rheumatoid arthritis were the major diseases for which trials had been conducted, reflecting the pleiotropic actions of curcumin. In these trials, curcumin often acted as a dietary supplement or an adjunct treatment to the standard therapy. Studies on the efficacy and safety of curcumin as adjuvant in the treatment of cancer and cognitive damage will continue to dominate in future clinical trials (Jurenka, 2009). In their review on the clinical effects of curcumin in ulcerative colitis, Kumar et al. (2012) suggested that curcumin may be a safe and effective therapy for the maintenance of remission when given as adjunct therapy in quiescent ulcerative colitis. However, the results were preliminary due to the low number of enrolled patients participated in the clinical trials, as suggested by Fürst and Zündorf (2014). They suggested more thorough controlled randomized trials are required to be pursued to determine the safety level and efficacy of the compound for human use. The success of curcumin as a potent anti-inflammatory agent in future depends on the findings of high-quality and big cohort studies. Moreover, curcumin has poor bioavailability, and many studies have been carried out to address this issue via chemical and technological methods. Preparation of more stable curcumin derivatives and use of nanotechnology for curcumin delivery are actively being pursued to improve the bioavailability of curcumin (Anand et al., 2007). Curcumin still has potential to be used clinically for the treatment of the abovementioned indications as it is nontoxic with good safety profile and well tolerated.

\section{Xanthorrhizol}

Xanthorrhizol is a bisabolane-type sesquiterpenoid, isolated from C. zanthorrhiza Roxb. It is known to possess diverse pharmacological activities, including antioxidant, antiinflammatory, antimicrobial, anticancer, hepatoprotective, nephroprotective, antihypertensive, antihyperglycemic, antiestrogenic, and antiplatelet effects. Xanthorrhizol reduced mRNA levels of MMP-2, MMP-8, NF- $\kappa$ B p65, and IL- $1 \beta$ in LPS-induced human gingival fibroblast- 1 cells. The compound also has anti-inflammatory activities in $\mathrm{H}_{2} \mathrm{O}_{2}$-treated $\mathrm{HT} 22$ hippocampal cells and inhibited MAPK/activator protein-1 (AP-1) signaling pathways (Kim et al., 2018). In a study to evaluate the effects of standardized C. zanthorrhiza extract and its marker compound, xanthorrhizol, on hyperglycemia and 
inflammatory markers in high-fat diet-induced obese mice, xanthorrhizol was found to significantly inhibit inflammatory cytokine release, such as IL- $1 \beta$, IL- 6 , TNF- $\alpha$, and C-reactive protein (CRP), in the liver, muscle, and adipose tissue (Kim M-B et al., 2014).

\section{Other Compounds}

In addition to curcuminoids, sesquiterpenes like turmeronols have potential to suppress the immune response. Turmeronol A and turmeronol B from C. longa were tested on mouse macrophages (RAW 264,7 cells). Both turmeronols showed inhibitory of $\mathrm{PGE}_{2}$ and NO production as well as IL-6 and IL$1 \beta$ at the mRNA and protein levels in LPS-induced cells. Turmeronols also inhibited the translocation of NF- $\kappa \mathrm{B}$ from the cytoplasm into the nucleus (Okuda-Hanafusa et al., 2019). Curdione, a major compound of $C$. aeruginosa, has been proposed as a potential immunomodulatory agent. Molecular docking analysis revealed that there is a high probability of interaction between curdione and CD95 protein, as the replacement of native ligand. The docking score of curdione to the protein was lower than that of the native ligand. In addition, 1,8-cineol from $C$. aeruginosa also has a high docking score to CD95 protein, but not significant as compared to those of native ligand of CD95 (Anggriani et al., 2019). Isocurcumenol isolated from C. zedoaria did not demonstrate any significant toxicity on normal chicken embryo lymphocytes and fibroblast cells (Lakshmi et al., 2011). A recent study showed that five sesquiterpenoids (isoprocurcumenol, germacrone, curzerenone, curcumenol, and curcuzedoalide) from C. zedoaria demonstrated inhibitory activity on NO synthesis. Among the compounds, curcuzedoalide showed the highest inhibition. Further study showed that curcuzedoalide inhibited the expression of proinflammatory mediators (iNOS and COX-2) (Lee et al., 2019). Curcumin, dihydrocurcumin, tetrahydrodemethoxycurcumin, and tetrahydrobisdemethoxycurcumin in C. zedoaria enhanced the release of IL- 4 and TNF- $\alpha$, and inhibited the production of $\beta$ hexosaminidase. $\beta$-Hexosaminidase is a marker of antigenIgE-mediated degranulation (Putri, 2014).

Isolated compounds from C. zedoaria, that is, epiprocurcumenol, procurcumenol, and 1,7-bis(4hydroxyphenyl)-1,4,6-heptatrien-3-one, inhibited the production of TNF- $\alpha$ from LPS-activated macrophages (Jang, et al., 2001). These compounds, especially 1,7-bis(4hydroxyphenyl)-1,4,6-heptatrien-3-one, were also found to exhibit strong inhibition against production of $\mathrm{NO}$ and expression of iNOS in activated macrophages (Jang et al., 2004). Demethoxycurcumin, bisdemethoxycurcumin, and 3buten-2-one, 4-[(1R, 4aR, 8aR)-decahydro-5, 5, 8a-trimethyl-2methylene-1-naphthalenyl]- (3E)-rel isolated from C. manga reduced the production of NO from LPS-stimulated RAW 264.7 cells. Among the compounds tested, demethoxycurcumin showed the highest NO inhibition (Kaewkroek et al., 2009). In an effort to elaborate the antiinflammatory mechanism of compounds from C. mangga rhizomes, Kaewkroek et al. (2010) evaluated the antiinflammatory effects of several compounds against production of $\mathrm{PGE}_{2}$ and $\mathrm{NO}$ from RAW 264.7 cells. These include demethoxycurcumin,

bisdemethoxycurcumin, 15,16 bisnorlabda-8 (17),11-dien-13-one, and (E)-15,15diethoxylabda-8 (17),12-dien-16-al. Of all the compounds tested, 11-dien-13-one (E)-15,15-diethoxylabda-8 (17),12-dien16-al demonstrated the strongest NO inhibitory activity, while demethoxycurcumin displayed the strongest activity on $\mathrm{PGE}_{2}$ release. Moreover, investigation of mechanism at the transcriptional level showed that all the compounds reduced the mRNA expressions of COX-2 and iNOS, except 15,16 bisnorlabda-8 (17), 11-dien-13-one, which only downregulated the mRNA of iNOS.

Most of the studies on the bioactive secondary metabolites of Curcuma species were carried out at cellular and molecular levels on various immune cells to explore their effects on the release and expression of pro-inflammatory mediators via various signaling pathways, such as NF- $\kappa \mathrm{B}, \mathrm{MAPKs}$, and other events. More indepth studies to understand the underlying mechanisms using experimental in vivo animal models of immune-related disorders and elaborate bioavailability, preclinical pharmacokinetics, and toxicity studies are required before clinical trials can be pursued for development into immunomodulatory agents.

\section{TOXICOLOGICAL STUDIES}

Systematic safety evaluations and toxicological investigations on C. longa and curcumin have indicated that they are nontoxic for human consumption, especially by oral administration. It is considered non-genotoxic, non-mutagenic, and generally recognized as safe. Several studies have indicated that oral administration of C. longa and curcumin in animals was safe without reproductive toxicity at certain doses. Clinical trials have indicated that the safe dose for human consumption was at an oral dose of $6 \mathrm{~g} /$ day for 4-7 weeks. In rare cases, minor side effects like gastrointestinal upsets may happen (Soleimani et al., 2018). A cheminformatics approach was used to predict toxicity, which includes human hepatotoxicity, rodent carcinogenicity, and bacterial mutagenicity of 200 chemical compounds found in $C$. longa. Of the compounds studied, 136 compounds were predicted as mutagenic, 184 were toxigenic, 64 were hepatotoxic, and 153 were carcinogenic. Interestingly, a dose-dependent hepatotoxicity may occur with curcumin and its derivatives. The study also predicted that few other constituents of $C$. longa are noncarcinogenic, non-mutagenic, non-hepatotoxic, and devoid of any side effects (Balaji and Chemakam, 2010).

Liju et al. (2013) reported the acute and sub-chronic toxicity studies of the essential oil of C. longa (EOCL). For the acute toxicity test, up to $5 \mathrm{~g}$ of EOCL per $\mathrm{kg}$ body weight was administered in a single dose to Wistar rats, while for the subacute toxicity study, the rats were administered with a daily oral administration at doses of $0.1,0.25$, and $0.5 \mathrm{~g} / \mathrm{kg}$ for 13 weeks. The results indicated that the EOCL was nontoxic as there were no changes in body weight, and no mortality or adverse clinical signs during both acute and sub-chronic toxicity studies. The hepatic function was normal, and the biomarkers, alanine amino transferase (ALT), alkaline phosphatase (ALP), and aspartate aminotransferase (AST) 
remained unchanged in treated animals. There was no subacute toxicity as triglycerides, total cholesterol, serum electrolyte parameters, histopathology of tissues, and markers of renal function remained unchanged after 13 weeks of treatment with curcumin. There was no mutagenicity to Salmonella typhimurium up to $3 \mathrm{mg} /$ plate. Oral administration of $1 \mathrm{~g} / \mathrm{kg}$ body weight EOCL for 14 days did not produce any genotoxicity as there was no DNA damage and chromosome aberration or micronuclei in rat bone marrow cells (Mary et al., 2012).

The acute toxicity study of $C$. zanthorrhiza ethanol extract at $5000 \mathrm{mg} / \mathrm{kg}$ revealed that the extract did not show any toxicity signs such as salivation, sleeping, diarrhea, or lethargy in mice (Devaraj et al., 2010). The result was in accordance with a previous study which showed no toxicity sign was observed in rats after administration of C. zanthorrhiza ethanol extract at 2000 and $5000 \mathrm{mg} / \mathrm{kg}$. During 14 days of observation, rats showed no clinical toxic signs, such as hypoactivity, hyperactivity, lethargy, dermatitis, anorexia, depression, and jaundice as well as no abnormalities in the kidney and liver (Rahim et al., 2014). Listyawati (2006) reported the chronic toxicity study of ethanol extract of C. zanthorrhiza. The extract at $50 \mathrm{mg} / \mathrm{kg} /$ day did not induce significant effects on spermatogenic and hematological changes (Listyawati, 2006). C. zanthorrhiza supplement at $2000 \mathrm{mg} / \mathrm{kg}$ showed no significant abnormalities on the lung, heart, liver, kidney, and stomach. The $\mathrm{LD}_{50}$ of C. zanthorrhiza supplement as hepatoprotective was greater than $5000 \mathrm{mg} / \mathrm{kg}$ bw (Arifin et al., 2020). Based on a clinical study on 30 healthy subjects, the administration of $C$. zanthorrhiza in combination with Vitex trifolia at doses of 1,500 and 4,500 mg/day for 14 days did not alter the liver and kidney function, while at a dose of $9000 \mathrm{mg} / \mathrm{day}$, the administration altered the AST and serum creatinine values, indicating the extract affected the liver and kidney functions (Baroroh et al., 2011). An aqueous extract of $C$. zanthorrhiza at 2000 and $5000 \mathrm{mg} / \mathrm{kg}$ body weights also showed no toxicity in mice or rats. Xanthorhizol, the active constituent of C. zanthorrhiza, at a dose of $500 \mathrm{mg} / \mathrm{kg}$ did not cause mortality in mice (HMPC, 2014).

Our previous study reported the acute toxicity evaluation of ethanol extract of C. mangga rhizomes. Mice were administered with the extract at $500,1000,2000$, and $5000 \mathrm{mg} / \mathrm{kg}$ body weights as a single dose, followed by 14 days of observation. Signs of toxicity were revealed as lethargy was observed after treatment with $C$. mangga extract at doses of 2000 and $5000 \mathrm{mg} / \mathrm{kg}$ body weight. Meanwhile, other signs of toxicity such as diarrhea, coma, and salivation were not recorded. In addition, the extract did not cause deleterious effect on mice body weight. Macroscopic examination of two main organs (liver and kidney) showed that the texture and color of both organs were comparable to those of normal group. C. mangga extract at the dose of $5000 \mathrm{mg} / \mathrm{kg}$ caused sinusoidal dilation in the liver and glomerular lesion in the right kidney; however, there was no lesion in the left kidney. The extract at the highest dose did not cause mortality; hence, it can be considered that the $\mathrm{LD}_{50}$ of $C$. mangga extract was estimated to be more than $5000 \mathrm{mg} / \mathrm{kg}$ body weight (Yuandani and Suwarso, 2017a).

The cytotoxicity evaluation of $C$. aeruginosa rhizomes on fibroblast test has been conducted by Yuliawati and Hestianah (2010). The results revealed that the extract at the concentrations ranging from 1 to $25 \mathrm{ppm}$ was not toxic, as indicated by the percentage of cell viability ranging from 81.60 to $90.57 \%$ (Yuliawati and Hestinah, 2010). Sub-chronic toxicity evaluation of $C$. aeruginosa starch was conducted in Wistar rats. C. aeruginosa starch was administered daily for 90 days. The observation was performed for 90 days and followed until 120 days for satellite group to evaluate the reversible or irreversible effect. The hematological parameters were observed, these include leukocytes, hemoglobin, red blood cell (RBC), hematocrit, mean corpuscular hemoglobin concentration (MCHC), mean corpuscular hemoglobin ( $\mathrm{MCH})$, mean corpuscular volume (MCV), and platelet levels. The results indicated that there was no toxic effect on hematological parameters (Kusumarin et al., 2020). C. aeruginosa in combination with Allium sativum, Terminalia bellirica, and Amomum compactum has been evaluated for their safety. Acute toxicity evaluation has been performed according to the fixed-dose method of OECD guideline 420. The herbal formulation did not cause any toxic signs and symptoms. The were no abnormalities found on body weight gain, macroscopic and microscopic examinations as well as the relative organ weight after treatment with the herbal preparation at the doses of 300 and $2000 \mathrm{mg} / \mathrm{kg}$ body weight. Further study on sub-chronic toxicity showed that the extracts did not induce any physical toxic symptoms as well as abnormal weight gain and hematological parameters. Moreover, the herbal formulation at a dose of $4,032 \mathrm{mg} / \mathrm{kg}$ did not cause any toxic effects on the liver and kidney, which was indicated by the normal values of urea, creatinine, total protein, albumin, globulin, aspartate aminotransferase (AST) or glutamic oxaloacetic transaminase (GOT), and alanine aminotransferase (ALT). In addition, macroscopic and microscopic examinations showed that there were no toxic effect on all organs tested (Sholikhah et al., 2020).

The evaluation of acute toxicity study of the purified fraction of $C$. zedoaria revealed that the fraction at the dose of 41.6 and $35.7 \mathrm{mg} / \mathrm{kg}$ did not significantly alter the liver and kidney enzyme levels. The $\mathrm{LD}_{50}$ was $500 \mathrm{mg} / \mathrm{kg}$ bw (Lakshmi et al., 2011). Furthermore, C. zedoaria ethanol extract at $150 \mathrm{mg} / \mathrm{kg} /$ day revealed a significant reduction of $\mathrm{RBC}, \mathrm{Hb}$ level, and spermatozoa quality in chronic toxicity evaluation (Listyawati, 2006). The essential oil of C. zedoaria at 100 or $200 \mathrm{mg} / \mathrm{kg}$ revealed weight loss, and abnormal hematological and biochemical changes on dams and embryos in GD17 pregnant rats. The toxicity mechanism may be related to placental calcification in angiogenesis (Zhou et al., 2013). Sudeepthi et al. (2014) reported the safety evaluation of $C$. amada rhizomes in short-term treatment. The acetone extract of $C$. amada $(500-2000 \mathrm{mg} / \mathrm{kg})$ was administered to the test animals. The results indicated that the highest dose tested did not cause mortality (Sudeepthi et al., 2014).

\section{CONCLUSION AND FUTURE DIRECTIONS}

In the last 20 years, many plants of the genus Curcuma especially C. longa, C. zanthorrhiza, C. amada, C. mangga, C. aeruginosa, and $C$. zedoaria and some of their bioactive compounds have been investigated for their immunomodulating effects on the 
immune system. Most of the studies were in vitro and in vivo and only a few of the preclinical studies have progressed into clinical studies. The up-to-date literature gathered indicated that the immunological investigations on the plant extracts were mainly preliminary with little mechanistic studies. Most of the studies were on the crude extracts of the rhizomes. The extracts were not appropriately characterized chemically or standardized to the bioactive marker compounds which were responsible for the activity. The contributions of the chemical constituents of the plant to the bioactivities were not clearly correlated and identified. It is necessary for the immunomodulatory activity studies of the plant extracts to be accompanied with analyses of their bioactive compounds and identification of the chemical markers for standardization purposes. The extracts used in these studies should be quantitative and qualitative analyzed by using validated analytical methods. Some of the bioactive compounds especially the curcuminoids (curcumin, demethoxycurcumin and bisdemethoxycurcumin) and some sesquiterpenoids have been isolated from the extracts and their mechanistic effects in modulating the immune system have been determined. However, more mechanistic studies should be carried out for in depth understanding of the modulating effects of the plant samples on the innate and adaptive immune system. Of all the Curcuma species investigated, the immunomodulatory effects of C. longa and its major compound, curcumin, were the most studied. Their modulatory effects on various signaling pathways at molecular level have been reported. However, extensive molecular work on the other Curcuma species need to be carried out. Despite the regulatory requirements for clinical studies and sufficient data have not been generated on preclinical testing, there were already reports on a few unsystematic case studies to evaluate the immunomodulating properties of Curcuma species in human. Some clinical trials have been conducted on $C$. zanthorrhiza but they were unsystematic and not well designed. There was also lack of sufficient preclinical

\section{REFERENCES}

Abas, F., Lajis, N. H., Israf, D. A., Khozirah, S., and Umi Kalsom, Y. (2006). Antioxidant and Nitric Oxide Inhibition Activities of Selected Malay Traditional Vegetables. Food Chem. 95, 566-573. doi:10.1016/j.foodchem. 2005.01.034

Adeshina, I., Aewale, Y. A., and Tiamiyu, L. O. (2017). Growth Performance and Innate Immune Response of Clarias gariepinus Infected with Aeromonas hydrophila Fed Diets Fortified with Curcuma longa Leaf. West. Afr. J. Appl. Ecol. 25, 87-99.

Afolayan, F. I. D., Erinwusi, B., and Oyeyemi, O. T. (2018). Immunomodulatory Activity of Curcumin-Entrapped poly d,l -lactic- Co -glycolic Acid Nanoparticles in Mice. Integr. Med. Res. 7, 168-175. doi:10.1016/j.imr.2018.02.004

Alambra, J. R., Alenton, R. R. R., Gulpeo, P. C. R., Mecenas, C. L., Miranda, A. P., Thomas, R. C., et al. (2012). Immunomodulatory Effects of Turmeric, Curcuma longa (Magnoliophyta, Zingiberaceae) on Macrobrachium rosenbergii (Crustacea, Palaemonidae) against Vibrio alginolyticus (Proteobacteria, Vibrionaceae). Aquac. Aquar. Conserv Legis. 5, 13-17.

Alsahli, A. A., Alaraidh, I. A., Rashad, Y. M., and Abdel razik, E. S. (2018). Extract from Curcuma longa L. Triggers the Sunflower Immune System and Induces Defence-Related Genes against Fusarium Root Rot. Phytopathol. Mediterr. 57, 26-36. doi:10.14601/Phytopathol_Mediterr-21176 data and the extracts were not appropriately standardized. For clinical studies, sufficient preclinical testing should be generated using standardized extracts, which include bioavailability, pharmacokinetic and toxicological studies, before they can be subjected to clinical studies. Of all the bioactive metabolites of Curcuma species, only curcumin is undergoing extensive clinical trials for its anti-inflammatory properties and potential use as an adjuvant in the treatment of cancer. Curcumin has showed significant ability to modulate the immune response in experimental and clinical studies. However, more systematic and operationally thorough controlled randomized trials are needed to prove its safety and efficacy for human use. Other compounds from Curcuma species such as xanthorrhizol, curdione, curcuzedoalide, isoprocurcumenol and turmeronols have also been reported to modulate various lineages of immune response. More in depth studies including elaborate bioavailability, preclinical pharmacokinetics and toxicity studies are required to understand the underlying mechanisms and safety level before clinical trials can be pursued for development into potent and safe immunomodulatory agents.

\section{AUTHOR CONTRIBUTIONS}

All authors participated in the concept and preparation of draft, revised the manuscript, and approved the final version for submission to this journal.

\section{FUNDING}

This work was funded by the Ministry of Education and Culture Republic of Indonesia under the World Class University Program Year 2020. The grant number is $1879 /$ UN5.1.R/SK/ PPM/2020.

Anand, P., Kunnumakkara, A. B., Newman, R. A., and Aggarwal, B. B. (2007). Bioavailability of Curcumin: Problems and Promises. Mol. Pharmaceutics 4, 807-818. doi:10.1021/mp700113r

Anggriani, L., Yasmin, A., Wulandari, A. R., Leksono, G. M., Ikawati, M., and Meiyanto, E. (2019). Extract of Temu Ireng (Curcuma aeruginosa Roxb.) Rhizome Reduces Doxorubicin-Induced Immunosuppressive Effects. AIP Conf. Proc. 2099, 020001. doi:10.1063/1.5098406

Anisuzzama, M., Sharmin, S. A., Mondal, S. C., Sultana, R., Khalekuzza, M., Alam, I., et al. (2008). In vitro Microrhizome Induction in Curcuma zedoaria (Christm.) Roscoe-A Conservation Prioritized Medicinal Plant. J. Biol. Sci. 8, 1216-1220. doi:10.3923/jbs.2008.1216.1220

Arifin, P. F., Setiawan, I. M., PurwantiningsihAstuti, R. B., Azima, F., Susilowidodo, R. A., et al. (2020). Acute Toxicity Evaluation of Temulawak (Curcuma xanthorrhiza Roxb.) Hepatoprotective Supplement. Res. J. Pharm. 11 (2), 13-18. doi:10.33887/rjpbcs/2020.11.2.3

Aristyani, S., Widyarti, S., and Sumitro, S. B. (2018). Network Analysis of Indigenous Indonesia Medical Plants for Treating Tuberculosis. Pharmacogn. J. 10, 1159-1164. doi:10.5530/pj.2018.6.198

Arshad, L., Md. Areeful Haque, Md. A., Bukhari, S. N. A., and Jantan, I. (2017). An Overview of Structure-Activity Relationship Studies of Curcumin Analogs as Antioxidant and Anti-Inflammatory Agents. Future Med. Chem. 9, 605-626. doi:10.4155/fmc-2016-0223

Artfire (2016). Rare Curcuma amada. Available at: https://www.artfire.com/ (Accessed December 1, 2020). 
Arunkumar, P., Ramasubramanian, V., and Munirasu, S. (2016). Effect of Curcuma longa Enriched Mesocylops Thermocyclopoides on Fresh Water Fish, Cyprinus carpio. Int. J. Res. Dev. Pharm. L. Sci. 6, 2848-2492.

Astana, P. R. W., Ardiyanto, D., and Mana, T. A. (2018). Change in quality of life and CD4+ value on HIV/AIDS patients with immuostimulant Jamu Formula in Sragen regency. Indonesian J. Clin. Pharm. 7, 227-235. doi:10.15416/ijcp.2018.7.4.227

Ayati, Z., Ramezani, M., Amiri, M. S., Moghadam, A. T., Rahimi, H., Abdollahzade, A., et al. (2019). Ethnobotany, Phytochemistry and Traditional Uses of Curcuma spp. and Pharmacological Profile of Two Important Species (C. longa and C. zedoaria): A Review. Cpd 25, 871-935. doi:10.2174/ 1381612825666190402163940

Ayodele, V. O., Olowe, O. M., Afolabi, C. G., and Kehinde, I. A. (2018). Identification, Assessment of Diseases and Agronomic Parameters of Curcuma amada Roxb (Mango ginger). Curr. Plant Biol. 15, 51-57. doi:10. 1016/j.cpb.2018.10.001

Balaji, S., and Chempakam, B. (2010). Toxicity Prediction of Compounds from Turmeric (Curcuma longa L). Food Chem. Toxicol. 48 (10), 2951-2959. doi:10. 1016/j.fct.2010.07.032

Baroroh, H. N., Ikawati, Z., and Sudarman, K. (2011). A Safety Study of Extract Combination of Legundi (Vitex trifolia L.) Leaves and Temulawak (Curcuma xanthorrhiza R.) Rhizome as Anti-allergy in Healthy Volunteers. Int. J. Pharm. Pract. 2, 165-170.

Beutler, B. (2004). Innate Immunity: An Overview. Mol. Immunol. 40, 845-859. doi:10.1016/j.molimm.2003.10.005

Beyaert, R., Beaugerie, L., Van Assche, G., BrochezRenauld, L. J. C., Renauld, J.-C., Viguier, M., et al. (2013). Cancer Risk in Immune-Mediated Inflammatory Diseases (IMID). Mol. Cancer 12, 98. doi:10.1186/1476-4598-12-98

Bogdan, C. (2001). Nitric Oxide and the Immune Response. Nat. Immunol. 2, 907-916. doi:10.1038/ni1001-907

Carvalho, F., Vassão, R., Nicoletti, M., and Maria, D. (2010). Effect of Curcuma zedoaria Crude Extract against Tumor Progression and Immunomodulation. J. Venom. Anim. Toxins Incl. Trop. Dis. 16, 324-341. doi:10.1590/s167891992010000200013

Castro, C. N., Barcala Tabarrozzi, A. E., Winnewisser, J., Gimeno, M. L., Antunica Noguerol, M., Liberman, A. C., et al. (2014). Curcumin Ameliorates Autoimmune Diabetes. Evidence in Accelerated Murine Models of Type 1 Diabetes. Clin. Exp. Immunol. 177, 149-160. doi:10.1111/cei.12322

Chanda, S., and Ramachandra, T. V. (2019). Phytochemical and Pharmacological Importance of Turmeric (Curcuma longa): A Review. Res. Rev. J. Pharm. 9, $16-23$.

Chandrasekaran, C. V., Sundarajan, K., Kannan, J. R., Gururaja, G. M., Mundkinajeddu, D., and Agarwal, A. (2013). Immune-Stimulatory and Anti-inflammatory Activities of Curcuma longa Extract and its Polysaccharide Fraction. Pharmacognosy Res. 5, 71-79. doi:10.4103/09748490.110527

Chapel, H., Haeney, M., Misbah, S., and Snowden, N. (2006). Clinical Immunology. 5th Edn. Massachusetts: Blackwell Publishing.

Choudhury, D., Ghosal, M., Das, A. P., and Mandal, P. (2013). Development of Single Node Cutting Propagation Techniques and Evaluation of Antioxidant Activity of Curcuma aeruginosa Roxnurgh Rhizome. Int. J. Pharm.Sci. Res. 5, 227-234.

Cianciulli, A., Calvello, R., Porro, C., Trotta, T., Salvatore, R., and Panaro, M. A. (2016). PI3k/Akt Signalling Pathway Plays a Crucial Role in the Antiinflammatory Effects of Curcumin in LPS-Activated Microglia. Int. Immunopharmacol. 36, 282-290. doi:10.1016/j.intimp.2016.05.007

Devaraj, S., Esfahani, A. S., Ismail, S., Ramanathan, S., and Yam, M. F. (2010). Evaluation of the Antinociceptive Activity and Acute Oral Toxicity of Standardized Ethanolic Extract of the Rhizome of Curcuma xanthorrhiza Roxb. Molecules 15 (4), 2925-2934. doi:10.3390/ molecules 15042925

Dewi, M., Aries, M. H., Dwiriani, C. M., and Januwati, N. (2012). Knowledge on Health Benefit of Curcuma and the Clinical Trial of Its Effect on Humoral Immune System in Obese Adults. Indones. J. Agric. 17, 166-171.

Dosoky, N. S., and Setzer, W. N. (2018). Chemical Composition and Abiological Activities of Essential Oils of Curcuma Species. Nutrients 10, 1196. doi:10.3390/ nu10091196

Drugbank (2021). Curcuma xanthorrhiza oil. Available at: https://go.drugbank. com/drugs/DB11265 (Accessed January 26, 2021).
Dutta, B. (2015). Study of Secondary Metabolite Constituents and Curcumin Contents of Six Different Species of Genus Curcuma. J. Med. Plants Stud. 3, 116-119.

Economou, M., Zambeli, E., and Michopoulos, S. (2009). Incidence and Prevalence of Crohn's Disease and its Etiological Influences. Ann. Gastroenterol. 22, 158-167.

Elgert, K. D. (2009). Immunology Understanding the Immune System. 2nd Edn. Virginia: A John Wiley \& Sons, Inc., Publication.

Ervintari, F., Puspitawati, R., and Utami, S. (2019). Effect of Curcuma Xanthorrhiza Roxb. Ethanol Extract on the Viability of Streptococcus Mutans and Streptococcus Sanguinis Dual-Species Biofilms. Int. J. App. Pharm. 11, 75-78. doi:10.22159/ijap.2019.v11s1.181

Faradilla, M., and Iwo, M. I. (2014). Immunomodulatory Effect of Polysaccharide from White Turmeric [Curcuma zedoria (Christm.) Roscoe)]. Indonesian J. Pharm. 12, 73-278.

Firtel, R. A., and Chung, C. Y. (2000). The Molecular Genetics of Chemotaxis: Sensing and Responding to Chemoattractant Gradients. BioEssays 22, 603-615. doi:10.1002/1521-1878(200007)22:7<603::aid-bies3>3.0.co;2-\#

Flores, G. (2017). Curcuma longa L. Extract Improves the Cortical Neural Connectivity during the Aging Process. Neural Regen. Res. 12, 875-880. doi:10.4103/1673-5374.208542

Fu, Y., Gao, R., Cao, Y., Guo, M., Wei, Z., Zhou, E., et al. (2014). Curcumin Attenuates Inflammatory Responses by Suppressing TLR4-Mediated NF- $\mathrm{KB}$ Signaling Pathway in Lipopolysaccharide-Induced Mastitis in Mice. Int. Immunopharmacol. 20, 54-58. doi:10.1016/j.intimp.2014.01.024

Fürst, R., and Zündorf, I. (2014). Plant-Derived Anti-Inflammatory Compounds: Hopes and Disappointments Regarding the Translation of Preclinical Knowledge into Clinical Progress. Mediators Inflamm. 2014, 146832. doi:10. $1155 / 2014 / 146832$

Gao, X., Kuo, J., Jiang, H., Deeb, D., Liu, Y., Divine, G., et al. (2004). Immunomodulatory Activity of Curcumin: Suppression of Lymphocyte Proliferation, Development of Cell-Mediated Cytotoxicity, and Cytokine Production in vitro. Biochem. Pharmacol. 68, 51-61. doi:10.1016/j.bcp.2004. 03.015

Geetha, S., Singh, V., Ram, M. S., Ilavazhagan, G., Banerjee, P. K., and Sawhney, R. C. (2005). Immunomodulatory Effects of Seabuckthorn (Hippophae rhamnoides L.) against Chromium (VI) Induced Immunosuppression. Mol. Cel. Biochem. 278, 101-109. doi:10.1007/s11010-005-7095-9

George, M., and Britto, S. J. (2015). Phytochemicaland Antioxidant Studies on the Essential Oil of the Rhizome of Curcuma Aeruginosa Roxb. Int. Res. J. Pharm. 6, 573-579. doi:10.7897/2230-8407.068113

Guimarães, A. F., Vinhas, A. C. A., Gomes, A. F., Souza, L. H., and Krepskya, P. B. (2020). Essential Oil of Curcuma longa L. Rhizomes Chemical Composition, Yield Variation and Stability. Quim. Nova 43, 909-913. doi:10.21577/0100-4042.20170547

Hardiwati, K. T., Seninha, M., Lay, B. W., and Yanti (2019). Curcuminoid Cider Fermented from Curcuma xanthorrhiza Curcuminoids Attenuates Gene Expression Related to Obesity-Induced Inflammation in Hypercholesterolaemic Rats. Int. Food Res. J. 26, 859-867.

Harun, N. H., Septama, A. W., and Jantan, I. (2015). Immunomodulatory Effects of Selected Malaysian Plants on the CD18/11a Expression and Phagocytosis Activities of Leukocytes. Asian Pac. J. Trop. Biomed. 5, 48-53. doi:10.1016/ s2221-1691(15)30170-2

Hassan, A. A. M., Yacout, M. H., Khalel, M. S., Hafsa, S. H. A., Ibrahim, M. A. R., Mocuta, D. N., et al. (2018). Effects of Some Herbal Plant Supplements on Growth Performance and the Immune Response in Nile Tilapia (Oreochromis Niloticus). Sciendo 1, 134-141. doi:10.2478/alife-2018-0020

Hong, G. W., Hong, S. L., Lee, G. S., Yaacob, H., and Malek, S. N. A. (2016). NonAqueous Extracts of Curcuma mangga Rhizomes Induced Cell Death in Human Colorectal Adenocarcinoma Cell Line (HT29) via Induction of Apoptosis and Cell Cycle Arrest at G0/G1 Phase. Asian Pac. J. Trop. Med. 9, 8-18. doi:10.1016/ j.apjtm.2015.12.003

HMPC (2017). Assessment report on Curcuma longa L. (C. domestica Valeton) rhizoma. London: European Medicines Agency, 1-5.

HMPC (2014). Assessment report on Curcuma xanthorrhiza Roxb. (C. xanthorrhiza D. Dietrich), rhizoma. London: European Medicines Agency, 15.

Huang, J. K., Kim, A. J., Sohn, J. H., Han, K. L., and Choo, J. H. (2010). Immunostimulating Polysaccharide Isolated from Curcuma xanthorrhiza and Manufacturing Method Thereof. Patent Appl. Publ., 1-11. 
Huang, Y., Xue, C., He, W., and Zhao, X. (2019). Inhibition Effect of Zedoary Turmeric Oil on Listeria Monocytogenes and Staphylococcus aureus Growth and Exotoxin Proteins Production. J. Med. Microbiol. 68, 657-666. doi:10.1099/ jmm.0.000949

Ikawati, Z., Hertiani, T., and Izzati, F. (2019). Immunomodulatory Activity of an Indonesian Herbal Formulation for Respiratory Disorder. Phcog Mag. 15, 130-134. doi:10.4103/pm.pm_314_18

Ilene, A., Sandhika, W., and Hasanatuludhhiyah, N. (2020). Effect of Javanese Turmeric (Curcuma xanthorrhiza) Extract on Hepatitis Model of AlcoholInduced Mice. Jurnal Kedokteran Brawijaya 1, 39-44. doi:10.21776/ub.jkb. 2020.031.01.8

Inzaugarat, M. E., Matteo, E. D., Baz, P., Lucero, D., Garcia, C. C., Ballerga, E. G., et al. (2017). New Evidence for the Therapeutic Potential of Curcumin to Treat Nonalcoholic Faty Liver Disease in Humans. Plos One 12 (3), e0172900. doi:10. 1371/journal.pone. 0172900

Jain, S. K., Rains, J., Croad, J., Larson, B., and Jones, K. (2009). Curcumin Supplementation Lowers TNF- $\alpha$, IL-6, IL-8, and MCP-1 Secretion in High Glucose-Treated Cultured Monocytes and Blood Levels of TNF- $\alpha$, IL-6, MCP1, Glucose, and Glycosylated Hemoglobin in Diabetic Rats. Antioxid. Redox Signaling 11, 241-249. doi:10.1089/ars.2008.2140

Jang, M. K., Lee, H. J., Kim, J. S., and Ryu, J.-H. (2004). A Curcuminoid and Two Sesquiterpenoids from Curcuma Zedoaria as Inhibitors of Nitric Oxide Synthesis in Activated Macrophages. Arch. Pharm. Res. 27, 1220-1225. doi:10.1007/bf02975885

Jang, M., Sohn, D., and Ryu, J.-H. (2001). A Curcuminoid and Sesquiterpenes as Inhibitors of Macrophage TNF- $\alpha$ Release from Curcuma Zedoaria. Planta Med. 67, 550-552. doi:10.1055/s-2001-16482

Jantan, I., Saputri, F. C., Qaisar, M. N., and Buang, F. (2012). Correlation between Chemical Composition of Curcuma domestica and Curcuma xanthorrhiza and Their Antioxidant Effect on Human Low-Density Lipoprotein Oxidation. Evid. Based Complement. Alternat. Med. 2012, 438356. doi:10.1155/2012/438356

Jantan, I., Harun, N. H., Septama, A. W., Murad, S., and Mesaik, M. A. (2011). Inhibition of Chemiluminescence and Chemotactic Activity of Phagocytes in vitro by the Extracts of Selected Medicinal Plants. J. Nat. Med. 65, 400-405. doi:10.1007/s11418-010-0492-8

Jatoi, S. A., Kikuchi, A., Gilani, S. A., and Watanabe, K. N. (2007). Phytochemical, Pharmacological and Ethnobotanical Studies in Mango Ginger (Curcuma amada Roxb.; Zingiberaceae). Phytother. Res. 21, 507-516. doi:10.1002/ptr. 2137

Jose, S., and Thomas, T. D. (2014). Comparative Phytochemical and Anti-Bacterial Studies of Two Indigenous Medicinal Plants Curcuma caesia Roxb. and Curcuma aeruginosa Roxb. Int. J. Green. Pharm. 8, 65-71. doi:10.4103/ 0973-8258.126828

Jurenka, J. S. (2009). Anti-Inflammatory Properties of Curcumin, a Major Constituent of Curcuma longa: A Review of Preclinical and Clinical Research. Altern. Med. Rev. 14, 141-153.

Kaewkroek, K., Wattanapiromsakul, C., and Tewtrakul, S. (2010). AntiInflammatory Mechanisms of Compounds from Curcuma mangga Rhizomes using RAW264.7 Macrophage Cells. Nat. Prod. Commun. 5, 1547-1550. doi:10.1177/1934578x1000501006

Kaewkroek, K., Wattanapiromsakul, C., and Tewtrakul, S. (2009). Nitric Oxide Inhibitory Substances from Curcuma mangga Rhizomes. Songklanakarin J. Sci. Technol. 31, 293-297.

Kalim, H., Handono, K., Khalasha, T., Pratama, M., Dantara, T. I., Wulandari, A., et al. (2017). Immune Modulation Effects of Curcumin in Pristane-Induced Lupus Mice. Indian J. Rheumatol. 12, 86-93. doi:10.4103/injr.injr_95_16

Kaliyadasa, E., and Samarasinghe, B. A. (2019). A Review on Golden Species of Zingiberaceae Family Around the World: Genus Curcuma. Afr. J. Agric. Res. 14, 519-531. doi:10.5897/AJAR2018.13755

Karchuli, M. S., and Pradhan, D. (2011). Curcuma amada Roxb. Rhizome Extract Modulates Cellular and Humoral Immune System. Pharmcologyonline 3, 947-952.

Kavitha, R., and Mahadevi, R. (2020). Phytochemical and Pharmacological Properties of Curcuma amada: A Review. Int. J.Pharm. Sci. Res. 11, 3546-3555. doi:10.26452/ijrps.v11i3.2510

Kim, A.-J., Kim, Y.-O., Shim, J.-S., and Hwang, J.-K. (2007). Immunostimulating Activity of Crude Polysaccharide Extract Isolated from Curcuma xanthorrhiza Roxb. Biosci. Biotechnol. Biochem. 71, 1428-1438. doi:10.1271/bbb.60241
Kim, G.-Y., Kim, K.-H., Lee, S.-H., Yoon, M.-S., Lee, H.-J., Moon, D.-O., et al. (2005). Curcumin Inhibits Immunostimulatory Function of Dendritic Cells: MAPKs and Translocation of NF-kB as Potential Targets. J. Immunol. 174, 8116-8124. doi:10.4049/jimmunol.174.12.8116

Kim, K. I., Shin, K. S., Jun, W. J., Hong, B. S., Shin, D. H., Cho, H. Y., et al. (2001). Effects of Polysaccharides from Rhizomes of Curcuma Zedoaria on Macrophage Functions. Biosci. Biotechnol. Biochem. 65, 2369-2377. doi:10. 1271/bbb.65.2369

Kim, M.-B., Kim, C., Song, Y., and Hwang, J.-K. (2014). Antihyperglycemic and Anti-Inflammatory Effects of Standardized Curcuma xanthorrhiza Roxb. Extract and Its Active Compound Xanthorrhizol in High-Fat Diet-Induced Obese Mice. Evid. Based. Complement. Alternat. Med. 2014, 205915. doi:10. $1155 / 2014 / 205915$

Kim, O. K., Yoo, S. A., Nam, D.-E., Kim, Y., Kim, E., Jun, W., et al. (2014). Immunomodulatory Effects of Curcuma longa L. Extract in LP-BM5 Murine Leukemia Viruses-Induced Murine Acquired Immune Deficiency Syndrome. J. Korean Soc. Food Sci. Nutr. 43, 1317-1324. doi:10.3746/jkfn.2014.43.9.1317

Kim, S., Kook, K. E., Kim, C., and Hwang, J.-K. (2018). Inhibitory Effects of Curcuma xanthorrhiza Supercritical Extract and Xanthorrhizol on LPSInduced Inflammation in HGF-1 Cells and RANKL-Induced Osteoclastogenesis in RAW264.7 Cells. J. Microbiol. Biotechnol. 28, 1270-1281. doi:10.4014/jmb.1803.03045

Kobayashi, S. D., Voyich, J. M., Burlak, C., and DeLeo, F. R. (2005). Neutrophils in the Innate Immune Response. Arch. Immunol. Ther. Exp. 53, 505-517.

Kumar, S., Ahuja, V., Sankar, M. J., Kumar, A., and Moss, A. C. (2012). Curcumin for Maintenance of Remission in Ulcerative Colitis. Cochrane Database Syst. Rev. 10, CD008424. doi:10.1002/14651858.CD008424.pub2

Kumolosasi, E., Ibrahim, S. N. A., Ahmad Shukri, S. M., and Ahmad, W. (2018). Immunostimulant Activity of Standardised Extracts of Mangifera Indica Leaf and Curcuma Domestica Rhizome in Mice. Trop. J. Pharm. Res. 17, 77-84. doi:10.4314/tjpr.v17i1.12

Kusumarin, N., Lianahand Hafsha, M. (2020). Evaluation of the Potential of Ireng Gathering Starch (Curcuma aeruginosa Roxb.) as Alternative Food Ingredients and the Processed Organoleptic Aspects. Int. J. Agric. Biol. Sci. 2, 71-76. doi:10. 5281/zenodo.3710771

Lakshmi, S., Padmaja, G., and Remani, P. (2011). Antitumour Effects of Isocurcumenol Isolated from Curcuma zedoaria Rhizomes on Human and Murine Cancer Cells. Int. J. Med. Chem. 2011, 253962. doi:10.1155/2011/ 253962

Lee, T. K., Trinh, T. A., Lee, S. R., Kim, S., So, H. M., Moon, E., et al. (2019). Bioactivity-Based Analysis and Chemical Characterization of AntiInflammatory Compounds from Curcuma zedoaria Rhizomes using LPSStimulated RAW264.7 Cells. Bioorg. Chem. 82, 26-32. doi:10.1016/j.bioorg. 2018.09.027

Lestari, M. D., Arief, M., and Satyantini, W. H. (2019). Addition of Curcuma (Curcuma xanthorrhiza) as an Antioxidant on African Catfish (Clarias gariepinus) Commercial Fish Feeding. Int. J. Civ. Eng. 10, 380-385.

Li, S., Yuan, W., Deng, G., Wang, P., Yang, P., and Aggarwal, B. B. (2011). Chemical Composition and Product Quality Control of Turmeric (Curcuma longa L.). Topharmcj 5, 28-54. doi:10.2174/2210290601102010028

Liju, V. B., Jeena, K., and Kuttan, R. (2013). Acute and Subchronic Toxicity as Well as Mutagenic Evaluation of Essential Oil from Turmeric (Curcuma longa L). Food Chem. Toxicol. 53, 52-61. doi:10.1016/j.fct.2012.11.027

Listyawati, S. (2006). Toxicity Studies of the Rhizome Curcuma xanthorrhiza Roxb. and Curcuma zedoaria Roscoe on Hematological and Male Reproduction System of Mice (Mus musculus L.). J. Nat. Prod. Biochem. 4 (1), 10-13. doi:10.13057/biofar/f040103

Liu, Y., and Nair, M. G. (2011). Labdane Diterpenes in Curcuma mangga Rhizomes Inhibit Lipid Peroxidation, Cyclooxygenase Enzymes and Human Tumour Cell Proliferation. Food Chem. 124, 527-532. doi:10. 1016/j.foodchem.2010.06.064

Lobo, R., Prabhu, K. S., Shirwaikar, A., and Shirwaikar, A. (2009). Curcuma zedoaria Rosc. (white turmeric): A Review of Its Chemical, Pharmacological and Ethnomedicinal Properties. J. Pharm. Pharmacol. 61, 13-21. doi:10.1211/ jpp/61.01.0003

Luckheeram, R. V., Zhou, R., Verma, A. D., and Xia, B. (2012). CD4+T Cells: Differentiation and Functions. Clin. Develop. Immunol. 2012, 1. doi:10.1155/ 2012/925135 
Luster, A. D. (2001). "Chemotaxis: Role in Immune Response," in Encyclopedia of Life Sciences. Massachusetts: Nature Publishing Grup, 1-12.

Malek, S. N. A., Lee, G. S., Hong, S. L., Yaacob, H., Wahab, N. A., Faizal Weber, J.F., et al. (2011). Phytochemical and Cytotoxic Investigations of Curcuma mangga Rhizomes. Molecules 16, 4539-4548. doi:10.3390/molecules16064539

Mary, H. P., Susheela, G. K., Jayasree, S., Nizzy, A., Rajagopal, B., and Jeeva, S. (2012). Phytochemical Characterization and Antimicrobial Activity of Curcuma xanthorrhiza Roxb. Asian Pac. J. Trop. Biomed. 2, S637-S640. doi:10.1016/s2221-1691(12)60288-3

Matsuda, H., Tewtrakul, S., Morikawa, T., Nakamura, A., and Yoshikawa, M. (2004). Anti-allergic Principles from Thai Zedoary: Structural Requirements of Curcuminoids for Inhibition of Degranulation and Effect on the Release of TNF- $\alpha$ and IL-4 in RBL-2H3 Cells. Bioorg. Med. Chem. 12, 5891-5898. doi:10. 1016/j.bmc.2004.08.027

Mauren, F. M., Yantiand Lay, B. W. (2016). Efficacy of Oral Curcuminoid Fraction from Curcuma xanthorrhiza and Curcuminoid Cider in High-Cholesterol Fed Rats. Pharmacogn. Res. 8, 153-159. doi:10.4103/0974-8490.181468

Miksusanti (2012). Lymphocyte Proliferation by Temu Lawak (Curcuma xanthorrhiza ROXB) Essential Oil. Int. Conf. Bioinform. Biomed. Eng. 29, 205-209.

Mooraki, N., Batmany, Y., Zoriehzahra, S. J., and Kakoolaki, S. (2019). Evaluating the Effect of using Turmeric (Curcuma longa) of Growth Performance and Hematological Parameters of the Ornamental Fish, Green Terror (Andinocara rivulatus). J. Surv. Fish. Sci. 5, 37-47. doi:10.18331/sfs2019.5.2.5

Morales, G. A., Noratto, G., and Talcott, S. U. M. (2012). Standardized Curcuminoid Extract (Curcuma longa 1.) Decreases Gene Expression Related to Inflammation and Interacts with Associated microRNAs in Human Umbilical Vein Endothelial Cells (HUVEC). Food Funct. 3, 1286-1293. doi:10.1039/c2fo30023k

Naderi, M., Akbari, M. R., Asadi, K. E., Khaksar, K., and Khajali, F. (2014). Effects of Dietary Inclusion of Turmeric (Curcuma longa) and Cinnamon (Cinnamomum verum) Powders on Performance, Organs Relative Weight and Some Immune System Parameters in Broiler Chickens. Poult. Sci. J. 2, 153-163. doi:10.22069/PSJ.2014.1963

Nan, F. H., Agus, P. A. S., MargieBargir, B., and Lee, M. C. (2014). The Effects of Curcuma zedoaria and Zingiber zerumbet on Non-Specific Immune Responses of Grouper Epinephelus coioides. Iran. J. Fish. Sci. 14, 598-611.

Okamoto, A., Noble, E. E., Tyagi, E., Ying, Z., Zhuang, Y., and Gomez-Pinilla, F. (2015). Curcumin Boosts DHA in the Brain: Implications for the Prevention of Anxiety Disorders. Biochim. Biophys. Acta (BBA) - Mol. Basis Dis. 1852, 951-961. doi:10.1016/j.bbadis.2014.12.005

Okuda-Hanafusa, C., Uchio, R., Fuwa, A., Kawasaki, K., Muroyama, K., Yamamoto, Y., et al. (2019). Turmeronol A and Turmeronol B from Curcuma longa Prevent Inflammatory Mediator Production by Lipopolysaccharide-Stimulated RAW264.7 Macrophages, Partially via Reduced NF-кB Signaling. Food Funct. 10, 5779-5788. doi:10.1039/c9fo00336c

Oon, S. F., Nallappan, M., Tee, T. T., Shohaimi, S., Kassim, N. K., Sa'ariwijaya, M. S. F., et al. (2015). Xanthorrhizol: A Review of its Pharmacological Activities and Anticancer Properties. Cancer Cel. Int. 15, 1-15. doi:10.1186/s12935-0150255-4

Palpu, P., Rao, C. V., Rawat, A. K. S., Pjha, S. K., and Reddy, G. D. (2008). AntiAllergic Herbal Formulation. U.S. Patent No 7344739 B2. Washington, DC: U.S. Patent and Trademark Office.

Pan, M. H., Wu, J. C., Ho, C. T., and Badmaev, V. (2017). Effect of Water Extract of Curcuma longa (L.) Roots on Immunity and Telomerase Function. J. Complement. Integr. Med. 14, 1-6. doi:10.1515/jcim-2015-0107

Park, S.-J., Lee, D., Lee, M., Kwon, H.-O., Kim, H., Park, J., et al. (2018). The Effects of Curcuma longa L., Purple Sweet Potato, and Mixtures of the Two on Immunomodulation in C57BL/6J Mice Infected with LP-BM5 Murine Leukemia Retrovirus. J. Med. Food 21, 689-700. doi:10.1089/jmf.2017.4093

Patil, U. S., Jaydeokar, A. V., and Bandawane, D. D. (2012). Immunomodulators: A Pharmacological Review. Int. J. Pharm. Sci. 4, 30-36.

Pawitan, J. A. (2020). Curcumin as Adjuvant Therapy in COVID-19: Friend or Foe?. J. Int. Dent. Med. Res. 13, 824-829.

Pisani, L. F., Lecchi, C., Invernizzi, G., Sartorelli, P., Savoini, G., and Ceciliani, F. (2009). In vitro Modulatory Effect of $\omega$-3 Polyunsaturated Fatty Acid (EPA and DHA) on Phagocytosis and ROS Production of Goat Neutrophils. Vet. Immunol. Immunopathol. 131, 79-85. doi:10.1016/j.vetimm.2009.03.018
Policegoudra, R. S., Divakar, S., and Aradhya, S. M. (2006). Identification of Difurocumenonol, a New Antimicrobial Compound from Mango Ginger (Curcuma amada Roxb.) Rhizome. J. Appl. Microbiol. 102, 1594-1602. doi:10.1111/j.1365-2672.2006.03186.x

Policegoudra, R. S., Aradhya, S. M., and Singh, L. (2011). Mango Ginger (Curcuma amada Roxb.) - A Promising Spice for Phytochemicals and Biological Activities. J. Biosci. 36, 739-748. doi:10.1007/s12038-011-9106-1

Purwanti, S., Agustina, L., Syamsu, J. A., Adriyansyah, A., and Latief, M. F. (2018). Turmeric (Curcuma domestica) and Garlic (Allium sativum) towards Broiler Immune System Infected by Salmonella pullorum Bacteria as a Feed Additive. IOP Conf. Ser. Earth Environ. Sci. 247, 1-6. doi:10.1088/1755-1315/247/1/ 012063

Putri, M. S. (2014). White Turmeric (Curcuma zedoaria): Its Chemical Substance and the Pharmacological Benefit. J. Majority 3, 88-93.

Rahayu, D. U. C., Setyani, D. A., Dianhar, H., and Sugita, P. (2020). Phenolic Compounds from Indonesian White Turmeric (Curcuma zedoaria) Rhizomes. Asian J. Pharm. Clin. Res. 13, 194-198. doi:10.22159/ajpcr.2020.v13i7.38249

Rahim, N. A., Hassandarvish, P., Golbabapour, S., Ismail, S., Tayyab, S., and Abdulla, M. A. (2014). Gastroprotective Effect of Ethanolic Extract of Curcuma xanthorrhiza Leaf against Ethanol-Induced Gastric Mucosal Lesions in Sprague-Dawley Rats. Biomed. Res. Int. 2014, 416409. doi:10. $1155 / 2014 / 416409$

Rajkumari, S., and Sanatombi, K. (2017). Nutritional Value, Phytochemical Composition, and Biological Activities of Edible Curcuma Species: A Review. Int. J. Food Prop. 20, S2668-S2687. doi:10.1080/10942912.2017. 1387556

Rattue, G. (2012). Autoimmune Disease Rates Increasing. Medical News Today. Available at: http://www.medicalnewstoday.com/articles/246960.php (Accessed February 15, 2015).

Ravikumar, N., and Naga Kavitha, C. (2020). Therapeutic Potential of Curcumin on Immune Dysregulation in Comorbid Diabetic Asthma in Mice. Biomed. Pharmacol. J. 13, 821-831. doi:10.13005/bpj/1948

Ruangsang, P., Tewtrakul, S., and Reanmongkol, W. (2010). Evaluation of the Analgesic and Anti-Inflammatory Activities of Curcuma mangga Val and Zijp Rhizomes. J. Nat. Med. 64, 36-41. doi:10.1007/s11418-009-0365-1

Saroj, P., Verma, M., Jha, K. K., and Pal, M. (2012). An Overview on Immunomodulation. J. Adv. Sci. Res. 3, 7-12.

Sasikumar, B. (2005). Genetic Resources of Curcuma: Diversity, Characterization and Utilization. Plant Genet. Resour. 3, 230-251. doi:10.1079/pgr200574

Sengupta, M., Sharma, G. D., and Chakraborty, B. (2011). Hepatoprotective and Immunomodulatory Properties of Aqueous Extract of Curcuma longa in Carbon Tetra Chloride Intoxicated Swiss Albino Mice. Asian Pac. J. Trop. Biomed. 1, 193-199. doi:10.1016/s2221-1691(11)60026-9

Sethy, K., Swain, P., Behera, K., Sahoo, N., Agrawalla, J., Khandanga, S., et al. (2017). Effect of Turmeric (Curcuma longa) Supplementation on Antioxidants and Immunity of Broiler Birds. Livest. Sci. 8, 103-106. doi:10.4081/ijas.2015. 3870

Setiawati, M. C., Ikawati, Z., and Kertia, I. N. (2017). Antiinflamatory and Antidepressive Activities of Extract Curcuma xanthorrhiza Roxb in Systemic Lupus Erythematosus. Indonesian J. Pharm. 28, 185-190. doi:10.14499/ indonesianjpharm28iss3pp185

Setyati, W., Subagiyo, S., Pramesti, R., and Pramesti, D. (2019). Effectiveness of Herbal Extract (Piper retrofractum, Curcuma aeruginosa, and Curcuma zanthorrhiza) as Immunomodulator in Non-Specific Immunity System of Tiger Grouper (Epinephelus fuscoguttatus) against Infection from Vibrio Alginolyticus and Vibrio Parah. Sci. Technol. Indones. 4, 94-100. doi:10. 26554/sti.2019.4.4.94-100

Shabana, M. H., Shahy, E. M., Taha, M. M., Mahdy, G. M., and Mahmoud, M. H. (2020). Phytoconstituents from Curcuma longa L. Aqueous Ethanol Extract and Its Immunomodulatory Effect on Diabetic Infected Rats. Egypt. Pharmaceut J. 14, 36-43. doi:10.4103/1687-4315.154713

Shaikh, P. Z. (2011). Cytokines \& Their Physiologic and Pharmacologic Functions in Inflammation: A Review. Int. J. Pharm. Life Sci. 2, 1247-1263.

Sholikhah, E. N., Mustofa, M., Nugrahaningsih, D. A. A., Yuliani, F. S., Purwono, S., Sugiyono, S., et al. (2020). Acute and Subchronic Oral Toxicity Study of Polyherbal Formulation Containing Allium sativum L., Terminalia bellirica (Gaertn.) Roxb., Curcuma aeruginosa Roxb., and Amomum compactum Sol. ex. Maton in Rats. Biomed. Res. Int. 2020, 8609364. doi:10.1155/2020/8609364 
Snapdeal (2020). Curcuma Amada. Available at: https://www.snapdeal.com/ (Accessed December 1, 2020).

Soleimani, V., Sahebkar, A., and Hosseinzadeh, H. (2018). Turmeric (Curcuma longa) and its Major Constituent (Curcumin) as Nontoxic and Safe Substances: Review. Phytotherapy Res. 32, 985-995. doi:10.1002/ptr.6054

Sudeepthi, N. L., Kumar, K. E., and Kola, P. K. (2014). Effect of Curcuma amada (mango ginger) Roxb. $\mathrm{n}$ Scopolamine Induced Memory Deficit in Rats. Int. J. Res. Pharm. Chem. 4, 1127-1134.

Sulfianti, A., Ningsih, S., and Agustini, K. (2019). Chemoprevention Effect of Curcuma aeruginosa in DMBA-Induced Cytokines Production. Int. Res. J. Pharm. 10, 54-59. doi:10.7897/2230-8407.100378

Sun, W., Wang, S., Zhao, W., Wu, C., Guo, S., Gao, H., et al. (2017). Chemical Constituents and Biological Research on Plants in the Genus Curcuma. Crit. Rev. Food Sci. Nutr. 57, 1451-1523. doi:10.1080/10408398.2016.1176554

Surh, Y.-J., Chun, K.-S., Cha, H.-H., Han, S. S., Keum, Y.-S., Park, K.-K., et al. (2001). Molecular Mechanisms Underlying Chemopreventive Activities of Anti-Inflammatory Phytochemicals: Down-Regulation of COX-2 and iNOS through Suppression of NF-kB Activation. Mutat. Res./Fundam. Mol. Mech. Mutagen. 480-481, 243-268. doi:10.1016/S0027-5107(01)00183-X

Tan, B., and Vanitha, J. (2004). Immunomodulatory and Antimicrobial Effects of Some Traditional Chinese Medicinal Herbs: A Review. Cmc 11, 1423-1430. doi:10.2174/0929867043365161

Thokchom, S. S., and Phucho, I. T. (2015). Elemental Analysis, Ditermination of Alkaloid, Saponin and Flavonoid of Three Selected Species of Zingiberaceae Family. Int. J. Pharm. Sci. Res. 6, 3044-3048. doi:10.13040/IJPSR.0975-8232. 6(7).3044-48

Tung, B. T., Nham, D. T., Hai, N. T., and Thu, D. K. (2019). Curcuma longa, the Polyphenolic Curcumin Compound and Pharmacological Effects on Liver. Dietary Interventions Liver Dis. 2019, 125-134. doi:10.1016/b978-0-12-8144664.00010-0

Uchio, R., Higashi, Y., Kohama, Y., Kawasaki, K., Hirao, T., Muroyama, K., et al. (2017). A Hot Water Extract of Turmeric (Curcuma longa) Suppresses Acute Ethanol-Induced Liver Injury in Mice by Inhibiting Hepatic Oxidative Stress and Inflammatory Cytokine Production. J. Nutr. Sci. 6, 1-9. doi:10.1017/jns. 2016.43

USDA (2021). Natural Resources Conservation Services. Plants Database. Available at: https://plants.usda.gov/java/ClassificationServlet? source $=$ display\&classid $=$ CURCU (Accessed January 25, 2021).

Wahono, C. S., Setyorini, C. D., Kalim, H., Nurdianaand Handono, K. (2017a). Effect of Curcuma xanthorrhiza Supplementation on Systemic Lupus Erythematosus Patients with Hypovitamin D which were Given Vitamin D3 towards Disease Activity (SLEDAI), IL-6, and TGF- $\beta 1$ Serum. Int. J. Rheumatol. 2017, 7687053. doi:10.1155/2017/7687053

Wahono, C. S., Wahyuni, Z. D., and Kalim, H. (2017b). Effect of Curcuma xanthorrhiza Suplementation in Vitamin D3 Administration towards Proteinuria, Serum Anti-dsDNA and IL-17 Levels on Systemic Lupus Erythematosus (sle) Patients with Hypovitamin. D Int. J. Clin. Rheumatol. $12,121-129$.

Warrington, R., Watson, W., Kim, H. L., and Antonetti, F. R. (2011). An Introduction to Immunology and Immunopathology. All Asth Clin. Immun. 7, S1. doi:10.1186/1710-1492-7-s1-s1

Weidner, M. S., Peterson, M. J., and Jacobsen, N. (2001). Certain Diterpenes and Extracts or Concentrates of Curcuma amada Containing Them for Use as Medicaments. U.S. Patent No 6235287 B1. Washington, DC: U.S. Patent and Trademark Office.

Win, N. N., Ito, T., Ngwe, H., Win, Y. Y., PremaOkamoto, Y., et al. (2017). Labdane Diterpenoids from Curcuma amada Rhizomes Collected in Myanmar and their Antiproliferative Activities. Fitoterapia 122, 34-39. doi:10.1016/j.fitote.2017. 08.006

Wu, A., Noble, E. E., Tyagi, E., Ying, Z., Zhuang, Y., Pinilla, F. G., et al. (2015). Curcumin boosts DHA in the brain: implications for the prevention of anxiety disorders. Biochim. Biophys. Acta 1852, 951-961. doi:10.1016/j.bbadis.2014. 12.005
Xia, X., Pan, Y., Zhang, W.-Y., Cheng, G., and Kong, L.-D. (2006). Ethanolic Extracts from Curcuma longa Attenuates Behavioral, Immune, and Neuroendocrine Alterations in a Rat Chronic Mild Stress Model. Biol. Pharm. Bull. 29, 938-944. doi:10.1248/bpb.29.938

Yadav, R. P., and Tarun, G. (2017). Versality of Turmeric: a Review the Golden Spice of Life. J. Pharmacogn. Phytochem. 6, 41-46.

Yadav, V. S., Mishra, K. P., Singh, D. P., Mehrotra, S., and Singh, V. K. (2005). Immunomodulatory Effects of Curcumin. Immunopharmacol. Immunotoxicol. 27, 485-497. doi:10.1080/08923970500242244

Yoo, S. A., Kim, O. K., Nam, D.-E., Kim, Y., Baek, H., Jun, W., et al. (2014). Immunomodulatory Effects of Fermented Curcuma longa L. Extracts on RAW 264.7 Cells. J. Korean Soc. Food Sci. Nutr. 43, 216-223. doi:10.3746/jkfn.2014. 43.2.216

Yoo, S. A., Kim, O. K., Nam, D. E., Park, S. J., Han, D. K., Kwon, H. O., et al. (2013). Immunomodulatory Effects of Curcuma longa L., Mulberry Leaves, and Purple Sweet Potato Extracts: Modulation of Immune Functions during Murine Leukemia Virus Infection. Nutrition 27, 1079. doi:10.1096/fasebj.27. 1_supplement.1079.18

Yu, Y., Shen, Q., Lai, Y., Park, S. Y., Qu, X., Lin, D., et al. (2018). Anti-Inflammatory Effect of Curcumin in Microglial Cells. Front. Pharmacol. 9, 1-10. doi:10.3389/ fphar.2018.00386

YuandaniNugraha, S. E., Laila, L., Silaban, S. D., and Ramadhani, F. (2020). Stimulatory Effect of Curcuma mangga on Immune Response against Staphylococcus aureus. Nusantara Biosci. 12, 109-113. doi:10.13057/ nusbiosci/n120204

Yuandani, Y., and Suwarso, E. (2017a). Acute Toxicity of Ethanol Extract of Curcuma mangga Rhizome. Asian J. Pharm. Clin. Res. 10, 383-385. doi:10. 22159/ajpcr.2017.v10i9.18398

Yuandani, Y., and Suwarso, E. (2017b). Immunomodulatory Effects of Ethanol Extract of Curcuma mangga Rhizomes in Mice. Asian J. Pharm. Clin. Res. 10, 383-385. doi:10.22159/ajpcr.2017.v10i9.18398

YuandaniYuliasmi, S., Satria, D, F., Dongoran, R, S., Sinaga, M. H. A., and Marpaung, N. (2019). Correlation between the Phytochemical Constituents of Curcuma mangga and Its Immunomodulatory Effect. Rasayan J. Chem. 12, 1-6. doi:10.31788/rjc.2019.1215050

YuandaniYuliasmi, S., Yuliasmi, S., and Satria, D. (2018). Analysis of Compounds and Immunostimulatory Properties of Curcuma mangga Rhizomes on Male Mice. Rasayan J. Chem. 11, 844-849. doi:10.31788/rjc.2018.1122097

Yue, G. L., Chan, B. C. L., Hon, P. M., Kennelly, E. J., Yeung, S. K., et al. (2010). Immunostimulatory Activities of Polysaccharide Extract Isolated from Curcuma longa. Int. J. Biol. Macrol. 47, 42-347. doi:10.1016/j.ijbiomac.2010.05.019

Yuliawati, T. H., and Hestinah, E. P. (2010). Cytotoxicity Effect of Curcuma aeruginosa Extract on Fibroblast with MTT Assay Method. Folia Med. Indonesiana. 46, 120-124.

Zhernakova, A., van Diemen, C. C., and Wijmenga, C. (2009). Detecting Shared Pathogenesis from the Shared Genetics of Immune-Related Diseases. Nat. Rev. Genet. 10, 43-55. doi:10.1038/nrg2489

Zhou, L., Zhang, K., Li, J., Cui, X., Wang, A., Huang, S., et al. (2013). Inhibition of Vascular Endothelial Growth Factor-Mediated Angiogenesis Involved in Reproductive Toxicity Induced by Sesquiterpenoids of Curcuma zedoaria in Rats. Reprod. Toxicol. 37, 62-69. doi:10.1016/j.reprotox.2013.02.001

Conflict of Interest: The authors declare that the research was conducted in the absence of any commercial or financial relationships that could be construed as a potential conflict of interest.

Copyright $\odot 2021$ Yuandani, Jantan, Rohani and Sumantri. This is an open-access article distributed under the terms of the Creative Commons Attribution License (CC $B Y)$. The use, distribution or reproduction in other forums is permitted, provided the original author(s) and the copyright owner(s) are credited and that the original publication in this journal is cited, in accordance with accepted academic practice. No use, distribution or reproduction is permitted which does not comply with these terms. 


\section{GLOSSARY}

ADMET absorption, distribution, metabolism, elimination, and toxicity

ALP alkaline phosphatase

ALT alanine amino transferase

AP-1 activator protein-1

AMPs antimicrobial peptides

APC antigen-presenting cells

AST aspartate aminotransferase

C5aR complement C5a receptor

CL chemiluminescence

CMS chronic mild stress

$\mathrm{CO}_{2}$ carbon dioxide

CRP C-reactive protein

DTH delayed hypersensitivity

EOCL essential oil of C. longa

fMLP formyl methionyl-leucyl-phenylalanine;

fMLPR formyl-methionyl-leucyl-phenylalanine receptor

GOT glutamic oxaloacetic transaminase

HFD- high-fat diet-

HOCl hypochlorous acid

HUVEC human umbilical vein endothelial cells

IBV infectious bronchitis virus

IBD inflammatory bowel diseases

IgM immunoglobulin M

IL-12 Interleukin 12

IL-6 interleukin-6
IL-1 $\beta$ interleukin-1 $\beta$

iNOS inducible nitric oxide synthase

ISI Institute for Scientific Information

IкB- $\boldsymbol{\alpha}$ I kappa B alpha

LPS lipopolysaccharide

MAPKs mitogen-activated protein kinases

MCHC mean corpuscular hemoglobin concentration

MCH mean corpuscular hemoglobin

MCP1 monocyte chemoattractant protein-1

MCV mean corpuscular volume

MIP1 $\alpha$ macrophage inflammatory protein-1a

MHC major histocompatibility complex

MPO myeloperoxidase

NO nitric oxide

NF-КB nuclear factor-kappa B

PAFR platelet-activating factor receptor

PGE2 prostaglandin E2

PHA-P phytohemagglutinin-P

PMNs polymorphonuclear cells

PMA phorbol 12-myristate 13-acetate

PUFAs polyunsaturated fatty acids

ROS reactive oxygen species

SLE systemic lupus erythematosus

sRBCs sheep red blood cells

T1D type 1 diabetes

TLC total leukocytes number

TNF- $\boldsymbol{\alpha}$ tumor necrosis factor-alpha. 